\title{
NADPH Oxidase as a Therapeutic Target for Oxalate Induced Injury in Kidneys
}

\author{
Sunil Joshi, ${ }^{1}$ Ammon B. Peck, ${ }^{2}$ and Saeed R. Khan ${ }^{1,3}$ \\ ${ }^{1}$ Department of Pathology, Immunology \& Laboratory Medicine, University of Florida College of Medicine, Gainesville, \\ FL 32610, USA \\ ${ }^{2}$ Department of Infectious Diseases \& Pathology, University of Florida College of Veterinary Medicine, Gainesville, FL 32610, USA \\ ${ }^{3}$ Department of Urology, University of Florida College of Medicine, Gainesville, FL 32610, USA
}

Correspondence should be addressed to Saeed R. Khan; khan@pathology.ufl.edu

Received 9 February 2013; Accepted 14 May 2013

Academic Editor: Kota V. Ramana

Copyright (c) 2013 Sunil Joshi et al. This is an open access article distributed under the Creative Commons Attribution License, which permits unrestricted use, distribution, and reproduction in any medium, provided the original work is properly cited.

A major role of the nicotinamide adenine dinucleotide phosphate (NADPH) oxidase family of enzymes is to catalyze the production of superoxides and other reactive oxygen species (ROS). These ROS, in turn, play a key role as messengers in cell signal transduction and cell cycling, but when they are produced in excess they can lead to oxidative stress (OS). Oxidative stress in the kidneys is now considered a major cause of renal injury and inflammation, giving rise to a variety of pathological disorders. In this review, we discuss the putative role of oxalate in producing oxidative stress via the production of reactive oxygen species by isoforms of NADPH oxidases expressed in different cellular locations of the kidneys. Most renal cells produce ROS, and recent data indicate a direct correlation between upregulated gene expressions of NADPH oxidase, ROS, and inflammation. Renal tissue expression of multiple NADPH oxidase isoforms most likely will impact the future use of different antioxidants and NADPH oxidase inhibitors to minimize OS and renal tissue injury in hyperoxaluria-induced kidney stone disease.

\section{Introduction}

In this review, we aim at focusing on the putative role of oxalate $\left(\mathrm{C}_{2} \mathrm{O}_{4}{ }^{2-}\right)$ leading to oxidative stress (OS) by production of reactive oxygen species (ROS) via different isoforms of nicotinamide adenine dinucleotide phosphate (NADPH) oxidase present in the kidneys. First, we provide a background of different types of hyperoxaluria and address the factors involved in oxalate and calcium-oxalate $(\mathrm{CaOx}-)$ induced injury in the kidneys. Second, we aim at addressing the role and different types of ROS and other free radicals, which when overproduced lead to OS and a brief description of different markers in the kidney which increase during OS. Third, we discuss the different isoforms of NADPH oxidase, their location, function, and expression in different cell types. Fourth, we address the pathophysiological role of NADPH oxidase in the kidneys and the regulation of NADPH oxidase (NOX enzymes). Finally, we discuss the role of antioxidants used for renal treatment and the different NADPH oxidase inhibitors involved in blocking NADPH oxidase from catalyzing production of superoxide with a potential of reducing OS and injury in the kidneys.

Oxalate, the conjugate base of oxalic acid $\left(\mathrm{C}_{2} \mathrm{H}_{2} \mathrm{O}_{4}\right)$, is a naturally occurring product of metabolism that at high concentrations can cause death in animals and less frequently in humans due to its corrosive effects on cells and tissues [1]. It is a common ingredient in plant foods, such as nuts, fruits, vegetables, grains, and legumes, and is present in the form of salts and esters [2-4]. Oxalate can combine with a variety of cations such as sodium, magnesium, potassium and calcium to form sodium oxalate, magnesium oxalate, potassium oxalate, and calcium oxalate, respectively. Of all the above oxalates, calcium oxalate is the most insoluble in water, whereas all others are reasonably soluble [5]. In normal proportions, it is harmlessly excreted from the body via the kidneys through glomerular filtration and secretion from the tubules $[6,7]$. Oxalate, at higher concentrations, leads to various pathological disorders such as hyperoxaluria, nephrolithiasis (formation and accumulation of $\mathrm{CaOx}$ crystals in the kidney), and nephrocalcinosis (renal 
calcifications) $[1,5,8,9]$. Hyperoxaluria is considered to be the major risk factor for $\mathrm{CaOx}$ type of stones [10] with nearly $75 \%$ of all kidney stones composed of $\mathrm{CaOx}$ [9]. These $\mathrm{CaOx}$ crystals, when formed, can be either excreted in the urine or retained in different parts of the urinary tract, leading to blockage of the renal tubules, injury to different kinds of cells in the glomerular, tubular and intestinal compartments of the kidney, and disruption of cellular functions that result in kidney injury and inflammation, decreased and impaired renal function [11, 12], and endstage renal disease (ESRD) [13, 14]. Excessive excretion of oxalate in the urine is known as hyperoxaluria and a significant number of individuals with chronic hyperoxaluria often have $\mathrm{CaOx}$ kidney stones. Dependent on food intake, a normal healthy individual is expected to have a regular urinary oxalate excretion somewhere between $10-40 \mathrm{mg} / 24 \mathrm{~h}$ $(0.1-0.45 \mathrm{mmol} / 24 \mathrm{~h})$. Anything over $40-45 \mathrm{mg} / 24 \mathrm{~h}(0.45-$ $0.5 \mathrm{mmol} / 24 \mathrm{~h}$ ) is regarded as clinical hyperoxaluria $[15,16]$. Hyperoxaluria can be commonly classified into three types: primary, secondary, and idiopathic. Primary hyperoxaluria in humans is generally due to a genetic defect caused by a mutation in a gene and can be further subdivided into three subgroups, type I-III. It is inherited in an autosomal recessive pattern and results in increased oxalate synthesis due to disorders of glyoxalate metabolism. There is inability to remove glyoxylate. Primary hyperoxaluria type I (PH I) is the most abundant of the three subgroups of primary hyperoxaluria (70-80\%) [13], caused by the incorrect sorting of hepatic enzyme alanine-glyoxylate aminotransferase (AGT) to the endosomes instead of the peroxisomes. AGT function is dependent on pyridoxal phosphate protein and converts glyoxalate to glycine. Owing to deficiency of AGT in PH I cases, glyoxalate is alternatively reduced to glycolate and oxidized to oxalate. In some cases of PH I, AGT is present but is misdirected to mitochondria where it remains in an inactive state. The metabolic defect of PH I is restricted to liver peroxisomes and the AGT fails to detoxify glyoxalate in the peroxisomes. Primary hyperoxaluria type II (PH II) results from the scarcity of hepatic enzyme glyoxylate reductase/hydroxypyruvate reductase (GRHPR) activity normally found in the cytosol. In studies, different cohorts have shown concentrations of urinary oxalate excretion between 88$352 \mathrm{mg} / 24 \mathrm{~h} \mathrm{(1-4} \mathrm{mmol} / 24 \mathrm{~h}$ ) for PH I and 88-176 mg/24 h (1$2 \mathrm{mmol} / 24 \mathrm{~h}$ ) for PH II $[13,17,18]$. In some cases, there is natural occurrence of AGT and GRHPR activities, but still there may be PH type III due to anion exchanger SLC26A6 and mutations in DHDPSL [13, 19-21]. All three types of PH show symptoms from infant to adolescence stages, with a majority showing clinical symptoms at 5 years in PH I to 15 years in PH II, and during the neonatal years in PH III [18]. Approximately, 35\% of patients with PH I may be unnoticed due to misinterpretation, lack or subtlety of the symptoms, until the onset of renal failure [13].

In contrast to primary hyperoxaluria, secondary hyperoxaluria appears to result from eating foods rich in highoxalate levels or exposure to large amounts of oxalate/oxalate precursors. Regular daily oxalate consumption by Western populations varies highly from 44 to $351 \mathrm{mg} /$ day (0.5$4 \mathrm{mmol} /$ day) but may exceed $1000 \mathrm{mg} /$ day $(11.4 \mathrm{mmol} /$ day $)$ when oxalate rich foods (e.g., spinach or rhubarb) are eaten in excess $[3,22-24]$. Exceedingly high values of up to $2045 \mathrm{mg}$ /day have also been reported due to consumption of seasonal foods consisting of purslane, pigweed, amaranth, and spinach [25]. There are different factors that affect dietary oxalate absorption such as oxalate bioavailability in the gut after it is consumed, number and accessibility of cations that attach to oxalate, such as calcium $\left(\mathrm{Ca}^{2+}\right)$ and magnesium $\left(\mathrm{Mg}^{2+}\right)$ in the gut, oxalate precursors and their effect on dietary oxalate, inherited absorption capacity, emptying of the gastrointestinal fluids, time taken for transit in the intestine, and the accessibility of oxalate degrading microorganisms such as Oxalobacter formigenes [15, 22-26]. A further subtype of hyperoxaluria is idiopathic hyperoxaluria which is spontaneous with unknown causes. Previous research has shown that idiopathic $\mathrm{CaOx}$ stone patients have the ability to absorb a greater quantity of oxalate as compared to normal individuals [27-29]. This may be true for why some autistic children have a high state of hyperoxaluria.

Previous studies have shown that dietary oxalate usually contributes just $10-20 \%$ of the urinary oxalate [9] but can be as high as $\sim 50 \%$, as oxalate is neither stored nor further metabolized inside the body [2]. Different studies have shown that foods rich in oxalate cause a transient state of hyperoxaluria, therefore difficult sometimes to detect in $24 \mathrm{~h}$ urinary samples $[4,30]$ Another mechanism for hyperoxaluria is fat malabsorption, also known as enteric hyperoxaluria. It can arise for two different reasons: (a) greater access of the mucous membrane in the intestine to oxalate caused by greater numbers of dihydroxy bile acids such as taurocholic and glycocholic acid and (b) interaction of fatty acids with calcium present in the lumen, augmenting the quantity of soluble oxalate when few insoluble $\mathrm{CaOx}$ complexes are formed [31]. This condition has been shown to be linked with bypass surgeries of small distal bowel or resections and other pathophysiological disorders in which grave steatorrhea occurs, for example, in pancreatic insufficiency and celiac spruce in both children and adults. Furthermore, patients who have had jejunoileal bypass surgery also tend to have higher rate of occurrence of enteric hyperoxaluria. Additional reasons for malabsorption include biliary obstruction, overgrowth of bacteria, and blind loop syndrome [31].

\section{Oxalate and Calcium Oxalate Induced Injury}

Studies have shown that oxalate and calcium oxalate cause renal injury leading to inflammation and other pathophysiological conditions in the kidneys [32-35]. Oxalate levels in the urine crosses the supersaturation limits, causing crystallization of $\mathrm{CaOx}$, calcium oxalate monohydrate (COM) deposition in the renal cells and tissues that leads to damage that ultimately results in end-stage renal failure [35]. Many studies have shown that oxalate and $\mathrm{CaOx}$ crystals lead to death of cells in in vitro analyses [32, 36, 37].

Oxalate ions are generated in the liver by glyoxalate metabolism, but due to low solubility they are carried at low concentrations in the plasma membrane [38]. Previous 
studies have shown that oxalate is quickly taken up by proximal tubule cells and high concentration of oxalate can be excreted in urine by the secretary pathway $[39,40]$. The major pathway of oxalate excretion from the body is via urinary excretion; however, a study in rats has shown that large quantities of oxalate can also be removed by the gastrointestinal system when there is kidney failure [41].

It is now well known that $\mathrm{CaOx}$ crystals cause injury to cells and tissues by causing damage to cell membranes, production of lipid mediators (prostaglandins, leukotrienes), and excessive production of reactive oxygen species, all of which lead to an imbalance between oxidants and antioxidants, with malfunctioning of mitochondria [42,43]. Studies have shown that $\mathrm{CaOx}$ crystals induce the phosphatidylserine imbalance in the membrane and greater production of ceramide, signals of cell death [42-44]. CaOx also causes hemolysis of red blood cells [45] and $\mathrm{CaOx}$ crystal injury may also be due to abundant release of ROS and other free radicals produced from molecular oxygen which ultimately lead to oxidative stress. Our review provides an insight on oxalate- and CaOXinduced renal injury due to different types of ROS produced by numerous enzyme complexes and mitochondria with special focus on NADPH oxidases leading to oxidative stress.

\section{Reactive Oxygen Species (ROS) and Oxidative Stress}

Reactive oxygen species are chemically reactive molecules and free radicals generated from molecular oxygen that, if produced in excess, cause damage to tissues and different components of the cells. Yet, if produced in physiological balance, ROS have been shown to play a principle role in normal cell signal transduction pathways, including apoptosis, gene expression, and activation of different cell signaling cascades. They are produced by different constitutively active oxidases such as NADPH oxidase, xanthine oxidase, lipoxygenase, cyclooxygenase, hemeoxygenase, and in the electron transport chain of mitochondria during cellular respiration $[1,46]$. Major cellular ROS include the superoxide anion $\left(\mathrm{O}_{2}^{-\bullet}\right)$, nitric oxide radical $\left(\mathrm{NO}^{*}\right)$, hydroxyl radical $\left(\mathrm{OH}^{*}\right)$, and hydrogen peroxide $\left(\mathrm{H}_{2} \mathrm{O}_{2}\right)$, all of which are produced by different signaling pathways $[1,46]$. The superoxide anion, precursor of the more powerful and complex oxidants, is mainly produced by the respiratory burst of phagocytes which is regarded as the most significant free-radical generator in vivo [47]. These ROS may react with chemicals and enzymes to generate additional oxidative species or become ineffective by nonenzymatic and enzymatic intercellular and intracellular reactions [48]. $\mathrm{O}_{2}{ }^{-\bullet}$ reacts with nitric oxide (NO) to produce peroxynitrite $\left(\mathrm{ONOO}^{-}\right)$which is a highly reactive and toxic nitrogen-containing species which nitrates proteins causing nitrative stress, augment platelet aggregation and vasoconstriction of the blood vessels [49]. Due to this reaction, there is diminished bioavailability of NO, a cellto-cell messenger, and this causes beneficial effects such as decreasing blood pressure [50]. Superoxide is highly reactive, has a short half-life, cannot cross the cell membrane, and is therefore acted on by the scavenging enzyme, superoxide dismutase (SOD), which converts it to hydrogen peroxide $\left(\mathrm{H}_{2} \mathrm{O}_{2}\right)$. Hydrogen peroxide is more stable as compared to superoxide and it diffuses though the lipid bilayer. Hydrogen peroxide $\left(\mathrm{H}_{2} \mathrm{O}_{2}\right)$ is further acted on by another scavenging enzyme, catalase (CAT), which neutralizes it to water and oxygen (Figure 1). In a metal catalyzed reaction, called the Haber-Weiss reaction, hydrogen peroxide yields a shortlived, short-ranged, and more reactive hydroxyl radical. Also, in the presence of $\mathrm{Fe}^{2+}$, a highly reactive hydroxyl radical $\left(\mathrm{OH}^{*}\right)$, is formed (Fenton reaction). Hydrogen peroxide, after oxidation by myeloperoxidase, gives rise to another extremely reactive oxygen species, hypochlorous acid $(\mathrm{HOCl})$. Hypochlorous acid is a powerful oxidizing agent which is known to alter lipid structure and function, other membranous components of the cells and proteoglycans. It acts on thiol groups of membranous proteins and is known to cause chlorinative stress [49]. Studies have shown that hypochlorous acid, along with hypobromous acid $(\mathrm{HOBr})$, and hypothiocyanous acids (HOSCN) have a role in antimicrobial defense by neutrophils $[48,51]$. These reactive oxygen species under normal conditions function as mediators in different cell signaling and regulatory pathways involving growth and proliferation, activation or inhibition of different molecules and in regulating different transcriptional activities. Signaling molecules that are controlled by these ROS include phosphatases, Ras, phospholipases, calcium signals, serine/theonine kinases and protein tyrosine kinases. ROS also regulate different nuclear factors such as nuclear factor- $\kappa \mathrm{B}(\mathrm{NF} \kappa \mathrm{B})$, transcription factor activation protein-1 (AP-1), and different genes such as c-myc, c-fos, and $c$-jun (1). ROS are also involved in initiation and implementation of programmed cell death (apoptosis). Under normal conditions, these ROS and reactive nitrogen species (RNS) are present at equilibrium with other antioxidants and are only generated when required and then vigorously removed by various scavenging enzymes and antioxidants. They play significant regulatory roles in various physiological processes, including innate immunity, modulation of redox-dependant signaling pathways, and as cofactors in the production of hormones.

ROS, when overproduced, can lead to oxidative stress. The majority of cells respond by increasing the levels of intracellular levels of antioxidants, but an excess of oxidants within a biological system leads to a change in the redox state, towards one that is more oxidizing $[52,53]$. Oxidative stress or abundance of ROS causes permanent damage to macromolecules and also causes interference in the important redox-dependant signaling processes [54]. Oxidative stress causes disruption of the nitric oxide (NO) signaling pathway [55]. NO has anti-inflammatory and vasodilator functions, but under excessive ROS, gets converted to peroxynitrite $[56,57]$, a powerful oxidant that causes oxidation of smallmolecule antioxidants such as glutathione, cysteine, and tetrahydrobiopterin [58]. Limited presence of tetrahydrobiopterin leads to uncoupling of endothelial nitric oxide synthase (eNOS), which in turn changes this enzyme from an NO-producing, vasoprotective enzyme to a superoxideproducing, oxidative stress enzyme $[59,60]$. Peroxynitrite is 


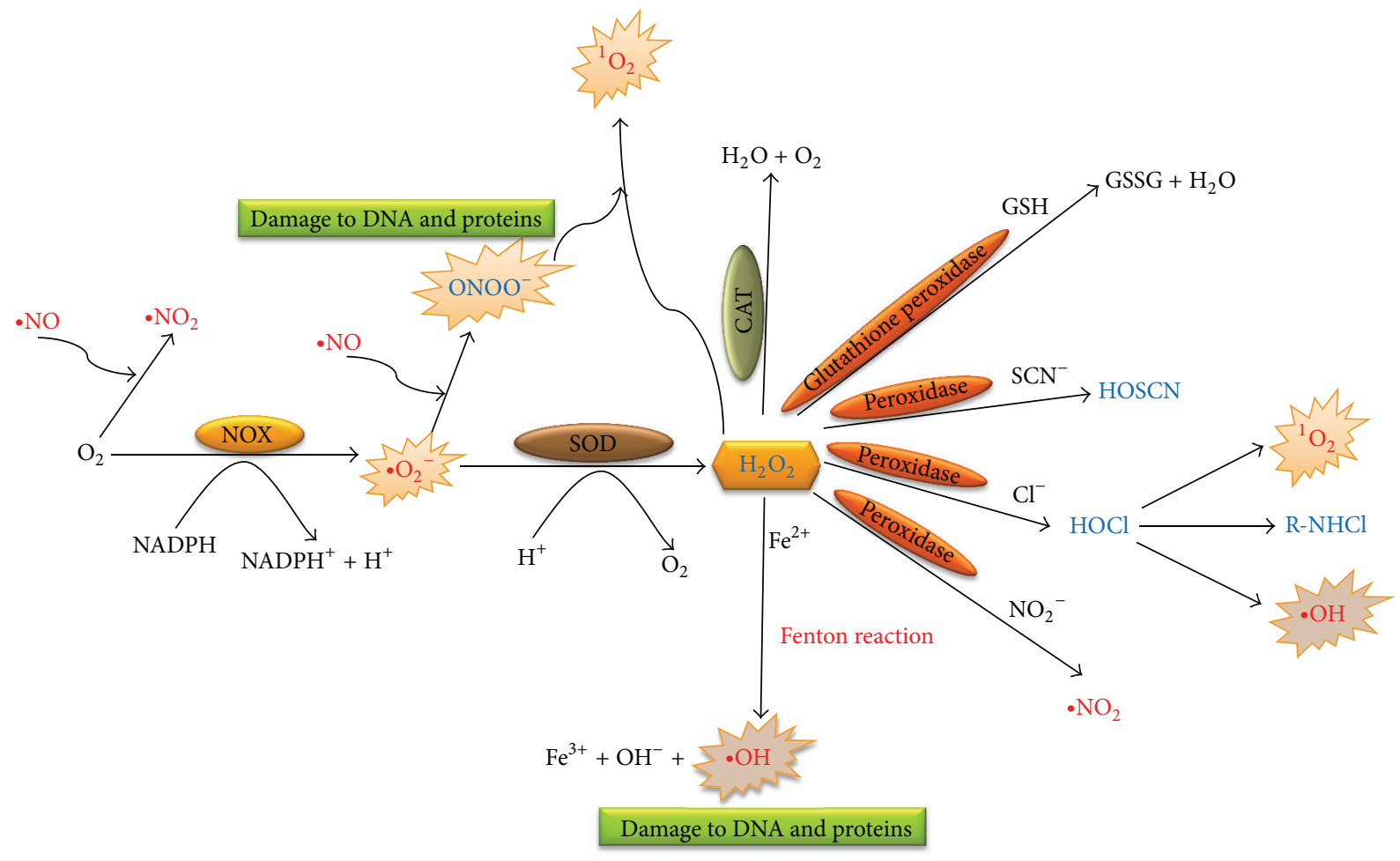

FIGURE 1: Production of ROS and different reactions. ROS with 1 free electron are shown in red and 2 free electrons are shown in blue. ROS, when produced in excess, cause damage to different components of the cell. Excess production of hydrogen peroxide $\left(\mathrm{H}_{2} \mathrm{O}_{2}\right)$ and peroxynitrite $\left(\mathrm{ONOO}^{-}\right)$leads to the production of singlet oxygen $\left({ }^{1} \mathrm{O}_{2}\right)$. The other radicals shown in the figure are superoxide $\left(\cdot \mathrm{O}_{2}{ }^{-}\right)$, nitric oxide $(\cdot \mathrm{NO})$, nitrogen dioxide $\left(\bullet \mathrm{NO}_{2}\right)$, hydroxyl radical $(\bullet \mathrm{OH})$, glutathione $(\mathrm{GSH})$, glutathione disulphide $(\mathrm{GSSG})$, thiocyanate $\left(\mathrm{SCN}^{-}\right)$, hypothiocyanous acid $(\mathrm{HOSCN})$, hypochlorous acid $(\mathrm{HOCl})$, and chroramine (R-NHCl). Figure modified from $[1,46]$.

very harmful and can hinder the activity or totally deactivate useful antioxidant enzymes such as superoxide dismutase, glutaredoxin, and glutathione reductase [58]. Peroxynitrite causes oxidation of the zinc thiolate center of NO synthase resulting in decreased formation of NO [61]. Decrease in $\mathrm{NO}$ can lead to increase in inflammation and remodeling of different biomolecules. Research has shown that ROS cause change in confirmation due to oxidation of proteins, such as kinases and phosphatases, and activation of nuclear factor$\kappa \mathrm{B}(\mathrm{NF} \kappa \mathrm{B})$ which play important roles in the regulation of immune response to infection [62]. NFאB is mainly involved in transcription where incorrect regulation can lead to inflammation, cancer, and autoimmune diseases. Activation of $\mathrm{NF} \kappa \mathrm{B}$ also leads to expression of adhesion molecules such as ICAM-1 (intercellular cell adhesion molecule-1), VCAM1 (vascular cell adhesion molecule-1), and E selectin on the endothelium [63]. $\mathrm{NF} \kappa \mathrm{B}$ activation also leads to proliferation and migration of vascular smooth muscle cells [64]. In this regard, ROS are also known to excite different cytosolic molecular complexes known as inflammasomes that have enzymatic activity mediated by the activation of caspase-1. Inflamasomes are involved in maturation and cleavage of cytokines such as IL-1 $\beta$ which is involved in inflammatory response [65].

There are a variety of markers in the kidneys which increase during oxidative stress. These include an increase in renal excretion of lipid peroxidation markers, but this increase in renal excretion is not a proof of increased ROS. Research has shown that there is greater excretion of 8Isoprostane, $\mathrm{PGF}_{2 \alpha}$, and malondialdehyde (MDA) by longtime infusion of ANG II in rats $[66,67]$. Also one study has shown that animals secrete significantly higher amounts of thiobarbituric acid reactive substances (TBARS) in the urine, generated as a byproduct of lipid peroxidation and an indication of oxidative stress in the kidneys [68]. The presence of $\alpha$-glutathione S-transferase ( $\alpha$-GST) in the urine of animals was also shown to be an indication of oxidative stress in the kidneys [68]. Oxidative stress is due to excessive production of ROS or reduction in antioxidants leading to production of free radicals that are injurious to all components of the cell including proteins, lipids, and DNA. Oxidative stress also leads to interruption in the normal signaling processes. $\beta$ galactosidase (GAL) and $\mathrm{N}$-acetyl- $\beta$-glucosaminidase (NAG), both markers of renal epithelial injury, also showed increased excretion in the urine [69]. Previous research has also shown greater urinary MDA, plasma MDA, and urinary NAG activity but diminished glutathione (GSH), cellular glutathione peroxidase (cGPx), protein thiol, and vitamin $\mathrm{E}$ activity observed in patients diagnosed with kidney stones which showed decreased urinary MDA, plasma MDA, and increased vitamin $\mathrm{E}$ after supplementation with potassium citrate (60 mEq/day for $1 \mathrm{month})$ [1]. There is also an increase 


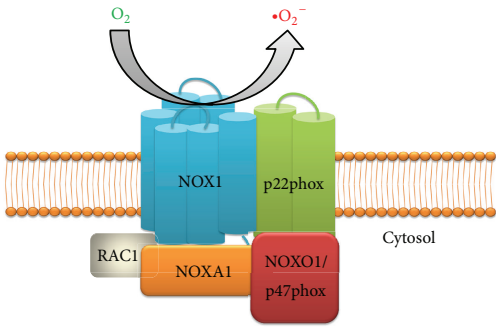

(a)

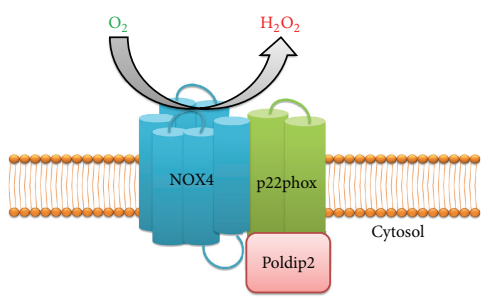

(d)

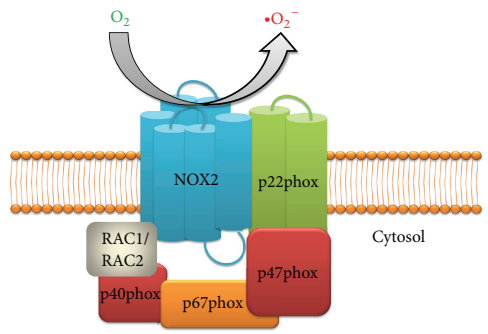

(b)

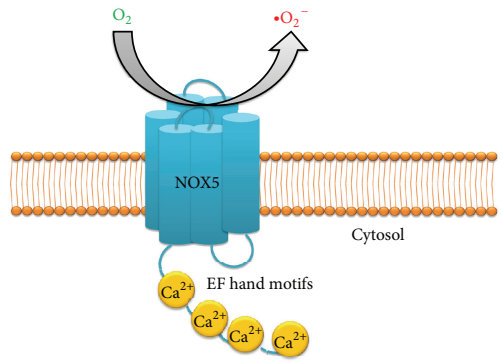

(e)

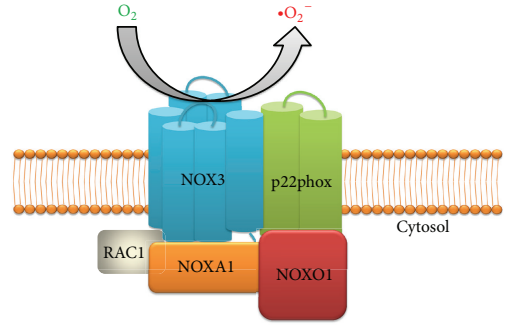

(c)

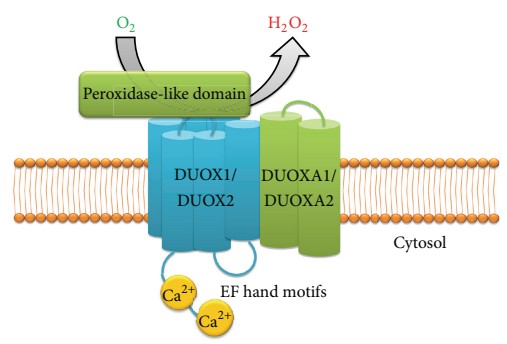

(f)

Figure 2: Seven different NOX isoforms-NADPH oxidase complexes. NOX isoform expression is relatively regulated at different transcriptional, post-transcriptional and translational levels under certain pathophysiological conditions. Most of the NOX isoforms have structural similarities to NOX2, with maximum in NOX3. NOX4 is most abundant in the kidneys in various kinds of cells. NOX4 is known to be constitutively active and do not require any subunits. NOX5 is directly activated by calcium. The core subunits of all the complexes (NOX1-NOX5, DUOX1/DUOX2) are shown in blue; their membrane bound subunits (p22phox, DUOXA1 and DUOXA2) are shown in green; the cytosolic subunits which acts as organizers (p40phox, NOXO1 and p47phox) are shown in red; activator subunits of NADPH oxidase complexes present in the cytosol (p67phox and NOXA1) are shown in orange; small GTPases (RAC1 and RAC2) are shown in grey; EF hand motifs are shown in yellow which bind with calcium to regulate the activity of NOX5, DUOX1 and DUOX2 (see text for details).

in the ROS-dependant products such as an increase in the renal nitrotyrosine immunoreactivity in kidneys of SHR [70], $2 \mathrm{k}, 1 \mathrm{C}$ rats [71]. Also, it is possible to take direct measurements of ROS such as superoxide production in the medulla [72] and the production of $\mathrm{H}_{2} \mathrm{O}_{2}$ by an ANG type 1 receptordependant mechanism in rats which helps us estimate the degree of oxidative imbalance in the kidneys [73]. These abovementioned markers provide an estimate of OS and renal injury but further studies and validation of all markers of OS would greatly augment our understanding of the role OS plays in causing renal injury.

\section{Isoforms of NADPH Oxidase}

To date, seven different isoforms of NADPH oxidase have been described. These are NADPH oxidase 1 (NOX1), NADPH oxidase 2 (NOX2), NADPH oxidase 3 (NOX3), NADPH oxidase 4 (NOX4), NADPH oxidase 5 (NOX5), Dual oxidase 1 (DUOX1), and Dual oxidase 2 (DUOX2). These isoforms are comprised of different core catalytic subunits: p22phox, p47phox, p67phox, p40phox, DUOX activator 1 (DUOXA1), DUOX activator 2 (DUOXA2), NOX activator 1 (NOXA1), and NOX organizer 1 (NOXO1) (Figure 2). These regulatory subunits are involved in different functions. While p22phox, DUOXA1, and DUOXA2 are responsible for the growth and expression of the NOX and DUOX core units in biological membranes, P67phox, and NOXA1 are involved in enzyme activation and p40phox, p47phox, and
NOXO1 in the spatial organization of different subunits of the enzyme [74]. RAC1 and RAC2 (small GTPases) may also be involved in the activation in some isoforms of NADPH oxidase, per se. Most of the isoforms generate superoxide except NOX4, DUOX1, and DUOX2 oxidases which directly generate $\mathrm{H}_{2} \mathrm{O}_{2}[75,76]$. NOX2 or gp91phox (91-kDa glycoprotein), previously known as mitogenic oxidase 1 (mox-1), along with p22phox (22-kDa protein) forms the two components of flavocytochrome $b_{558}$, a heterodimeric integral membrane protein [77]. NOX2 is a catalytic subunit which produces superoxide and is a protein which consists of six transmembrane domains with cytosolic $\mathrm{C}$ - and N-terminus [78]. Studies have shown that NOX2 has highest structural similarity with NOX3 (58\%), followed by NOX1 (56\%). NOX4 and NOX5 are remotely associated with NOX2 showing around $37 \%$ and $30 \%$ resemblance, respectively [77]. NOX5 has more structural similarity with the DUOX's subunits as they all have EF hand motifs (calcium-binding motifs) [77]. NOX1 isoform has been shown to be concerned with redoxdependent cell signaling and regulation of gene expression [79] and is mainly expressed in the colon epithelial cells [80]. However, other studies have shown NOX1 to be present in vascular smooth muscle cells (VSMC), sinusoidal endothelial cells, uterus, prostate, osteoclasts, placenta, retinal pericytes, and microglia [78]. NOX2 expression is well established in the phagocytes [81-83] but has also been observed in nonphagocytic cells such as neurons, hematopoietic stem cells, smooth muscle cells, endothelium, cardiomyocytes, 


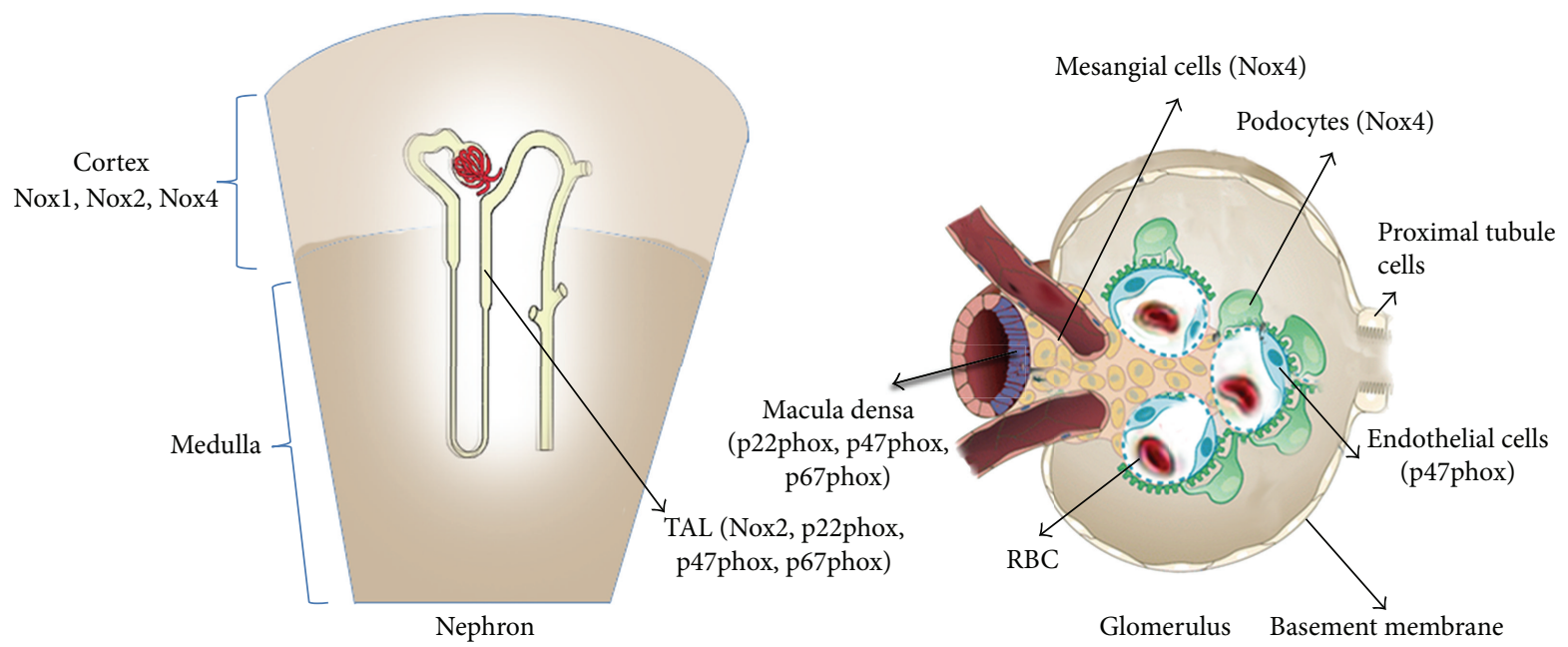

FIGURE 3: Different isoforms of NADPH oxidase complex present in different parts of the kidneys. The Nox isoforms expressed in the cortex and medulla as shown in the nephron and different cellular populations in the glomerulus (see text for details).

skeletal muscle cells, hepatocytes, and neutrophils [78, 81]. NOX3 isoform is known to be significantly expressed in the inner ear, fetal kidney, brain, and skull [84], while NOX3 has been shown to be favorably localized in cochlear and vestibular epithelial cells as well as spiral ganglion [78]. NOX4 isoform or renal NADPH oxidase (RENOX) is known to be highly expressed in the kidneys and is found in different cell types including neurons, smooth muscle cells, adipocytes, keratinocytes, hematopoietic stem cells, melanoma cells, fibroblasts, osteoclasts, and endothelial cells. NOX4 is the predominant isoform in the endothelial cells [85-88]. NOX5 isoform has been found in different parts of the body such as testis, vascular smooth muscles, ovaries, lymph nodes, myometrium, pancreas, spleen, and prostrate [89-91]. NOX5 has been involved in cell growth and thus far 5 subtypes, namely, $\operatorname{NOX} 5 \alpha, \beta, \delta, \gamma$, and $\varepsilon$, have been found [8992]. The other isoforms of NOX, DOUX1, and DOUX2 originally identified as thyroid oxidases have been extensively found in the thyroid [93], but also in prostate gland and airway epithelial cells. DUOX1 is expressed in bronchial and tracheal airway epithelial cells, whereas DUOX2 is found in epithelial cells of salivary glands, stomach, and brush border cells of various rectal glands such as caecum and sigmoidal colon [94]. All of these NOX isoforms play a significant role in the generation of ROS and oxidative stress. These enzymes are involved in many pathophysiological processes that are very crucial for different functions such as cellular signaling, regulation of gene expression, and cell differentiation.

\section{NADPH Oxidases in the Kidney}

Research has shown that NADPH oxidase in the kidneys may have a specific pathophysiological role; thus, it is present in different cellular compartments of the kidneys (Figure 3). The mammalian kidney consists of different cellular populations including mesangial cells, fenestrated endothelial cells, tubular epithelial cells of the proximal and distal nephron segments, glomerular podocytes, dendritic cells, and the cortical fibroblasts $[95,96]$. Previous research has shown that the main supplier of ROS in the form of superoxide $\mathrm{O}_{2}{ }^{-}$. in the renal cortex is NADPH oxidase, whereas in the renal medulla xanthine oxidase also makes similar contribution to $\mathrm{O}_{2}{ }^{-\bullet}$ generation along with NADPH oxidase [97]. Different subunits of the NADPH oxidase have also been shown to be abundantly present in the macula densa (MD), thick ascending loop of henle (TAL), interstitial cells, blood vessels, glomeruli, and tubules in the kidneys of spontaneously hypertensive rats (SHR) [98]. Previous studies in the human glomerular mesangial cells (HMC) have recognized $\alpha$ and $\beta$ subunits of cytochrome $b_{558}$ and the $45-\mathrm{kDa}$ flavoprotein [99]. Human glomerular mesangial cells produce ROS such as superoxide and express different NADPH oxidase subunits like p22phox, p67phox, and p47phox [100] and Nox4 [101, 102]. Studies have shown that the thick ascending loop of henle (TAL) in the outer medullary region expresses different NADPH oxidase subunits such as p40phox, p47phox, p22phox, and Nox2 [103]. Podocytes or visceral epithelial cells present around the capillaries of the glomerulus in the kidneys play a significant role in the functioning of the glomerular capillary wall. Research has shown the production of ROS in the cultured human podocytes and ROS was generated by NADPH oxidase and different subunits of NADPH oxidase such as p67phox, p47phox, Nox2, and p22phox were expressed in the podocytes, present in the glomerulus of the kidneys [104]. Nox4 has been shown as the most common Nox isoform to be expressed in the kidney epithelial cells $[105,106]$ and is distributed in the microvasculature, glomeruli, mesangial cells, and nephron segments $[102,105,107]$. Noxl, Nox2, and Nox4 have also been shown to be expressed in the renal cortex $[66,108]$. Chabrashvili et al. have shown the expression of p67phox, p22phox, and $\mathrm{p} 47 \mathrm{phox}$ in the renal cortex $[66,98]$. The same group compartmentalized the NADPH oxidase subunits in the renal cortex to macula densa, specific nephron segments in the 
TAL, cortical and medullary ducts, distal convoluted tubule, renal microvasculature and glomeruli $[66,98]$. P47phox which is also known as neutrophil cytosol factor-1 (Ncf-1) was found to be present in the endothelium and glomerular podocytes and p22phox subunit in the renal interstitial fibroblasts [98]. These studies give us an insight on the role of different NADPH oxidase subunits found and expressed in various subcompartments of the kidneys, making NADPH oxidase complex as one of the most important contributor of oxidative stress in the kidneys.

\section{Regulation of NADPH Oxidase (NOX Enzymes) Expression in the Kidney}

It is now well accepted that a significant amount of ROS production in mammalian cells is derived from the NADPH oxidase (NOX) of phagocytes (Phox), especially neutrophils and macrophages that catalyze the respiratory burst (i.e., the production of large number of ROS and utilization of large amounts of $\mathrm{O}_{2}$ ) [109]. Normally, the NADPH oxidase is nonfunctional but can be activated quickly when a cell comes in contact with different inflammatory biomolecules or microorganisms resulting in generation of ROS apart from mitochondrial production. Cytosolic NADPH oxidase is the electron donor for all the NADPH oxidase isoforms with molecular oxygen acting as the final electron acceptor. The electron transfer to molecular oxygen results in the release of superoxide from the oxidase enzyme in NOX1, NOX2, and NOX5 isoforms [110]. The other NOX isoforms such as NOX4, DUOX1, and DUOX2 oxidases do not directly release superoxide anion as their primary ROS; instead, they release hydrogen peroxide $[75,76]$. The NADPH oxidase complex consists of the membrane subunits Nox2 (gp91phox) and p22phox along with the regulatory cytosolic subunits p67phox, p47phox, p40phox, and the small GTPases protein, RAC [111].

Research has shown that NADPH oxidase is activated by Ang II infusion in the rat kidneys leading to increased expression of p22phox and Noxl in the renal cortex with concomitant reduction in the presence of Nox4 and SOD [66]. Also, high salt intake increased oxidative stress by increasing the expression of NOX2 and p47phox subunits and decreased SOD expression [108]. The prolonged effect of Angiotensin in the kidney has been shown to cause the activation of NADPH oxidase, enhanced expression of p22phox, and decrease in the scavenging enzyme SOD leading to renal cortical hypoxia, renal vasoconstriction, and hypertension [67]. The Noxl subunit has been shown to be upregulated in the rat-cultured vascular smooth muscle cells (VSMC) by PDGF, Ang II, and serum [112], whereas research has shown downregulation of Nox4 in the kidney cortex by the infusion of Ang II [108]. Ang II has been shown to upregulate p67phox expression in rabbit periadventitial fibroblasts [113] and the mouse aorta [114]. These research findings provide a brief insight on the role of angiotensin on the different subunits of $\mathrm{NADPH}$ oxidase and the regulation of expression of NADPH oxidase in the kidneys.

\section{Antioxidants for Renal Treatment}

Antioxidants have been shown to reduce oxidative stress. Treating the kidneys with vitamin E ( $\alpha$-tocopherol) along with mannitol removed the chances of deposition of $\mathrm{CaOx}$ crystals in rat kidneys injected with sodium oxalate [115]. Furthermore, antioxidants such as methionine, combination of vitamin $\mathrm{E}$ plus selenium, and glutathione monoester subdued $\mathrm{CaOx}$ crystals in the hyperoxaluric rat kidneys [116118]. However, recent studies have shown that it is not easy to remove oxidative stress with increased levels of antioxidants such as vitamin $\mathrm{E}$ in clinical trials [119-121]. These disparate observations cannot be regarded as proof against antioxidants as several clinical trials involved high risk patients in which the end-stage renal disease was quite advanced and doses of vitamin E differed greatly between trials. Antioxidant concentration is very critical in controlling oxidative stress because of the very high rate constants of the reactions between ROS and other molecules such as NO, certain amino acids, and nucleic acids. The reaction between NO and ROS happens at a rate of $1.9 \times 10^{10} \mathrm{M}^{-1} \mathrm{~S}^{-1}$ which is 6 times faster in magnitude than the reaction between superoxide and vitamin E $[122,123]$. Vitamin $\mathrm{E}$ in the body also faces a highly oxidizing environment one that can lead to rapid removal of reduced forms of antioxidants. It would seem that the best approach for reducing oxidative stress is by targeting the enzyme responsible for the generation of ROS, perhaps targeting NADPH oxidase by use of inhibitors of NADPH oxidase.

\section{NADPH Oxidase Inhibitors}

Identification of NADPH oxidase inhibitors is an ongoing active field, focused primarily on substances that obstruct a specific NADPH oxidase from catalyzing production of superoxide. NADPH oxidase inhibitors act through interference in the assembly of the NADPH oxidase complex by interacting with their subunits, blocking electron transfer decreasing production of ROS [124]. Table 1 lists a number of chemicals that alleviate oxidative stress through inhibiting ROS production by NADPH oxidases. In addition, Table 1 also describes the mode of action and pharmacologic effects of different peptide and nonpeptide inhibitors. These chemicals include, but are not limited to, Apocynin, diphenyleneiodonium chloride (DPI), pefabloc, proline-arginine rich antimicrobial peptide (PR-39), and new peptide inhibitors that have been developed to particularly target NADPH oxidases, such as gp91 ds-tat and novel nonpeptide VAS2870 [125]. The two most studied NADPH oxidase inhibitors are Apocynin and DPI. Apocynin, also known as 4-hydroxy-3-methoxy acetophenone or acetovanillone, is the best known inhibitor of NADPH oxidase to date. It was extracted from the roots of Apocynum cannabinum by Schmiedeberg in 1883 [126] and found to block the association of p47phox with membranebound p22phox subunit of the NADPH oxidase complex in leukocytes, monocytes, and endothelial cells and is also a scavenger of $\mathrm{H}_{2} \mathrm{O}_{2}$ [127]. At high concentration, it was shown to block Nox4, and Nox5 [128], making it more 
TABLE 1: Inhibitors of NADPH oxidase.

\begin{tabular}{|c|c|c|c|}
\hline Name & Mode of action & Pharmacological effects & References \\
\hline Apocynin & $\begin{array}{l}\text { NADPH oxidase complex assembly } \\
\text { inhibitor: inhibits binding of p47phox } \\
\text { with membrane bound p22phox }\end{array}$ & Scavenger of $\mathrm{H}_{2} \mathrm{O}_{2}$ & {$[130-132]$} \\
\hline DPI & $\begin{array}{l}\text { Inhibitor of flavoprotein, takes electrons } \\
\text { from FAD and prevents electron flow } \\
\text { through the flavocytochrome channel }\end{array}$ & $\begin{array}{l}\text { Inhibitor of NADH-ubiquinone oxidoreductase, } \\
\text { NADH dehydrogenase, xanthine oxidase, } \\
\text { cytochrome p } 450 \text { oxidoreductase, NOS, and } \\
\text { bacterial nicotine oxidase }\end{array}$ & [133-139] \\
\hline AEBSF & $\begin{array}{l}\text { Inhibits association of NOX2 subunit } \\
\text { with p47phox. Prevents binding of } \\
\text { p47phox and p67phox with cytochrome } \\
\text { b559 }\end{array}$ & Irreversible serine protease inhibitor & [140] \\
\hline Plumbagin & $\begin{array}{l}\text { Inhibits } \mathrm{O}_{2}^{-\bullet} \text { production in various cell } \\
\text { lines expressing NOX4 oxidase; unknown } \\
\text { mechanism }\end{array}$ & $\begin{array}{l}\text { Naphthoquinone structure may confer } \\
\text { ROS-scavenging effects }\end{array}$ & {$[141,142]$} \\
\hline PR-39 & $\begin{array}{l}\text { Inhibits } \mathrm{p} 47 \text { phox from binding to } \\
\text { p22phox subunit by cohering to } \mathrm{SH} 3 \\
\text { domains of } \mathrm{p} 47 \text { pphox }\end{array}$ & Non selective for NADPH oxidase & {$[143]$} \\
\hline S17834 & $\begin{array}{l}\text { Flavonoid derivative proposed to directly } \\
\text { inhibit NADPH oxidase activity, although } \\
\text { the mechanism is undefined }\end{array}$ & None & {$[144]$} \\
\hline VAS2870 & $\begin{array}{l}\text { Undefined mechanism: inhibits NADPH } \\
\text { oxidase activity in NOX2 } \\
\text { oxidase-containing HL- } 60 \text { cell line and in } \\
\text { vascular endothelial cells containing } \\
\text { NOX2 and NOX4 oxidases; does not } \\
\text { scavenge } \mathrm{O}_{2}^{-\cdot}\end{array}$ & None & {$[145,146]$} \\
\hline Gp91dstat & $\begin{array}{l}\text { Oxidase assembly inhibitor: inhibits } \\
\text { association of Nox } 2 \text { with p } 47 \text { phox. Does } \\
\text { not scavenge superoxide generated by } \\
\text { cell-free systems }\end{array}$ & None & {$[147,148]$} \\
\hline Statins & $\begin{array}{l}\text { Decrease superoxide production by } \\
\text { inhibiting synthesis of } \\
\text { farnesylpyrophosphate and } \\
\text { geranylgeranylpyrophosphate which are } \\
\text { crucial for membrane attachment of Rac } \\
\text { and NADPH oxidase assembly. May also } \\
\text { decrease p22phox and Noxl expression. } \\
\text { Likely to influence Noxl and Nox2 } \\
\text { activities }\end{array}$ & $\begin{array}{l}\text { HMG-CoA reductase inhibitor. Decreases AT1 } \\
\text { receptor expression; increases eNOS expression, } \\
\text { most effective for treating cardiovascular disease } \\
\text { with questionable benefit in those without } \\
\text { previous CVD but with elevated cholesterol levels }\end{array}$ & {$[149,150]$} \\
\hline $\begin{array}{l}\text { AT1 receptor } \\
\text { antagonists }\end{array}$ & $\begin{array}{l}\text { Decrease Ang II-dependent activation of } \\
\text { NADPH oxidase via AT1 receptors. } \\
\text { Unlikely to display Nox selectivity as Ang } \\
\text { II stimulates Noxl and Nox } 4 \text { oxidases }\end{array}$ & None. Controlling high blood pressure & {$[151]$} \\
\hline Nebivolol & $\begin{array}{l}\text { Inhibits membrane association and also } \\
\text { interaction of p67phox and Rac and } \\
\text { decreases oxidase expression. Inhibits } \\
\text { Noxl-dependent superoxide production }\end{array}$ & $\begin{array}{l}\beta \text {-adrenoceptor blocker, used in treatment of } \\
\text { hypertension }\end{array}$ & {$[152-155]$} \\
\hline Gliotoxin & $\begin{array}{l}\text { A fungal metabolite, thiol-modifying } \\
\text { toxin thought to inhibit phosphorylation } \\
\text { of p } 47 \text { phox by preventing PKC } \\
\text { colocalization with p } 47 \text { phox. Also, } \\
\text { inhibits electron transport through the } \\
\text { flavocytochrome before oxidase } \\
\text { activation. Low potency for blocking } \\
\text { Nox4 }\end{array}$ & $\begin{array}{l}\text { Stimulation of cGMP release. Cytoskeletal } \\
\text { reorganization. Disrupts the mitochondrial } \\
\text { membrane potential, possesses } \\
\text { immunosuppressive properties, } \\
\text { anti-inflammatory activity. }\end{array}$ & {$[75,156-160]$} \\
\hline
\end{tabular}


TABle 1: Continued.

\begin{tabular}{|c|c|c|c|}
\hline Name & Mode of action & Pharmacological effects & References \\
\hline $\begin{array}{l}\text { Clostridium difficile } \\
\text { toxin B }\end{array}$ & $\begin{array}{l}\text { Glycosylation of threonine- } 35 \text { on Rac, } \\
\text { which modifies GTPases activity }\end{array}$ & $\begin{array}{l}\text { Likely to inhibit all Rac-dependent protein } \\
\text { activity. High toxicity, vascular permeability and } \\
\text { inflammation }\end{array}$ & {$[161]$} \\
\hline $\begin{array}{l}\text { Nordihydroguaia- } \\
\text { retic } \\
\text { acid }\end{array}$ & $\begin{array}{l}\text { Blocks } \mathrm{H}_{2} \mathrm{O}_{2} \text { production in macrophages } \\
\text { in response to phorbol esters and in } \\
\text { endothelial cells in response to thrombin }\end{array}$ & $\begin{array}{l}\text { Lipooxigenase inhibitor. Blocks arachidonic acid } \\
\text { metabolism }\end{array}$ & {$[162-164]$} \\
\hline SKF525A & $\begin{array}{l}\text { Decreases superoxide and } \mathrm{H}_{2} \mathrm{O}_{2} \\
\text { production in endothelial cells }\end{array}$ & Cytochrome P450 inhibitor & {$[162,165]$} \\
\hline Metformin & $\begin{array}{l}\text { Scavenges hydroxyl radicals but not } \\
\text { superoxide. Could also inhibit PMA and } \\
\text { Ang II-dependent ROS production from } \\
\text { NADPH oxidase. However, this is likely } \\
\text { to be due to inhibition of PKC activity }\end{array}$ & Antihyperglycemic agent. PKC inhibitor & [166-168] \\
\hline Sildenafil-citrate & $\begin{array}{l}\text { Inhibitor of endothelial superoxide } \\
\text { production and gp91phox expression }\end{array}$ & $\begin{array}{l}\text { Inhibits phosphodiesterase type } 5 \text {. Nonselective } \\
\text { and in direct inhibitor for NADPH oxidase } \\
\text { isoforms. Have been shown to influence immune } \\
\text { system due to changes in gp91phox expression }\end{array}$ & {$[169-172]$} \\
\hline Bilirubin & $\begin{array}{l}\text { Inhibitor of superoxide production. No } \\
\text { effect on Nox2, p22phox and p } 47 \text { phox but } \\
\text { may reduce p47phox phosphorylation }\end{array}$ & ROS scavenger & {$[173-175]$} \\
\hline Minocycline & $\begin{array}{l}\text { Downregulates p67phox expression. } \\
\text { Inhibitor of superoxide generation in } \\
\text { microglia and dopaminergic neurons in } \\
\text { response to stimuli such as thrombin }\end{array}$ & Antibiotic & {$[176,177]$} \\
\hline Perhexiline & $\begin{array}{l}\text { Inhibits superoxide production in intact } \\
\text { neutrophils stimulated by fMLP or PMA. } \\
\text { Mechanism unknown }\end{array}$ & $\begin{array}{l}\text { Efficient antianginal agent that blocks } \\
\text { carnitine-palmitoyl-transferase }\end{array}$ & {$[178,179]$} \\
\hline Roxithromycin & $\begin{array}{l}\text { Inhibits superoxide generated by intact } \\
\text { neutrophils activated by fMPL or PMA } \\
\text { but not by cell lysates. No effect on } \\
\text { PKC-dependent phosphorylation. May } \\
\text { inhibit translocation of p47phox and/or } \\
\text { p67phox }\end{array}$ & $\begin{array}{l}\text { Macrolide antibiotic. Inhibit RNA-dependent } \\
\text { protein synthesis. Efficient in blocking } \\
\text { cytochrome P } 450\end{array}$ & {$[180-182]$} \\
\hline Taurine chloramines & $\begin{array}{l}\text { Inhibits translocation of p47phox and } \\
\text { p } 67 \text { phox to the membrane. Also inhibits } \\
\text { phosphorylation of p } 47 \text { phox. Reversible } \\
\text { inhibition of PMA-dependent superoxide } \\
\text { anion production in human neutrophils }\end{array}$ & Blocks inducible NOS in alveolar macrophages & {$[183,184]$} \\
\hline Resveratrol & $\begin{array}{l}\text { Reduces superoxide generation in intact } \\
\text { macrophages and homogenates. Does not } \\
\text { scavenge superoxide in cell-free systems }\end{array}$ & Inhibitor of $\mathrm{PKC}$ & [185-187] \\
\hline Curcurmin & $\begin{array}{l}\text { Reduces superoxide production in intact } \\
\text { macrophages and homogenates. Does not } \\
\text { scavenge superoxide in cell-free systems }\end{array}$ & $\begin{array}{l}\text { Irreversible inhibitor of thioredoxin reductase via } \\
\text { alkylation of cysteine residues }\end{array}$ & {$[185,188]$} \\
\hline Nitrolinoleate & $\begin{array}{l}\text { Nitrated lipid which blocks PMA- and } \\
\text { FMLP-dependent superoxide generation } \\
\text { and degranulation in human neutrophils } \\
\text { by enhancing cAMP but not cGMP levels }\end{array}$ & Also linked with increasing cAMP vasorelaxation & {$[189,190]$} \\
\hline Mycophenolate acid & $\begin{array}{l}\text { Fungal derivative that blocks endothelial } \\
\text { and neutrophil-derived superoxide by } \\
\text { reducing Rac levels. Does not alter mRNA } \\
\text { levels of Nox2, Nox4, and p47phox }\end{array}$ & $\begin{array}{l}\text { Efficient inhibitor of inosine monophosphate } \\
\text { dehydrogenase associated with purine synthesis in } \\
\text { B and T lymphocytes }\end{array}$ & {$[191,192]$} \\
\hline GK-136901 & $\begin{array}{l}\text { Well known NOX1 and NOX4 oxidase } \\
\text { inhibitor. Unknown mechanism, but } \\
\text { structural similarity with NADPH } \\
\text { suggests that it may act as a competitive } \\
\text { substrate inhibitor of this enzyme }\end{array}$ & None & {$[193,194]$} \\
\hline
\end{tabular}


TABLE 1: Continued.

\begin{tabular}{|c|c|c|c|}
\hline Name & Mode of action & Pharmacological effects & References \\
\hline ML171 & $\begin{array}{l}\text { Phenothiazine compound with selectivity } \\
\left.\text { for NOX1 oxidase ( } \mathrm{IC}_{50} \text { of } 0.25 \mu \mathrm{M}\right) \text { over } \\
\text { other NADPH oxidases }\left(\mathrm{IC}_{50}>3 \mu \mathrm{M}\right) \text {. } \\
\text { Does not scavenge oxygen radicals } \\
\text { generated by xanthine oxidase activity }\end{array}$ & None & [195] \\
\hline Mastoparan & $\begin{array}{l}\text { Inhibits superoxide production by } \\
\text { neutrophil lysates most likely via } \\
\text { interaction with N-terminal of p } 67 \text { phox }\end{array}$ & $\begin{array}{l}\text { An amphiphilic cationic tetradecapeptide isolated } \\
\text { from wasp venom. Has affinity towards } \mathrm{SH} 3 \\
\text { domains. Also interact with G-proteins }\end{array}$ & [196-199] \\
\hline Ghrelin & $\begin{array}{l}\text { Blocks superoxide production by thoracic } \\
\text { aorta most probably via release of NO. } \\
\text { Does not scavenge superoxide }\end{array}$ & $\begin{array}{l}\text { Capable of releasing growth hormone releasing } \\
\text { peptide. Stimulates gastric acid secretion }\end{array}$ & [200-202] \\
\hline Alpha tocopherol & $\begin{array}{l}\text { Inhibitor of p67phox-p } 47 \text { phox } \\
\text { translocation and p } 47 \text { phox } \\
\text { phosphorylation in monocytes, } \\
\text { neutrophils and microglial cells. This } \\
\text { effect is likely to be due to PKC inhibition }\end{array}$ & ROS scavenger & [203-206] \\
\hline Benzylisothiocyanate & $\begin{array}{l}\text { Concentration-dependent. Inhibits } \\
\text { TPA-induced superoxide production in a } \\
\text { human leukemia cell line. Does not affect } \\
\text { PKC activity and p } 47 \text { phox translocation. } \\
\text { Mechanism may involve covalent cysteine } \\
\text { modification of the NADPH oxidase }\end{array}$ & $\begin{array}{l}\text { May inhibit NO, PGE2 and TNF- } \alpha \text { production. } \\
\text { Also known to cause apoptosis via induction of } \\
\text { Bak and Bax proteins }\end{array}$ & [207-209] \\
\hline Probucol & $\begin{array}{l}\text { Known to reduce superoxide production } \\
\text { in rabbit aorta, by down-regulation of } \\
\text { p22phox }\end{array}$ & Free radical scavenger & {$[54,210-213]$} \\
\hline Nox2ds-tat & $\begin{array}{l}\text { Oxidase assembly inhibitor: inhibits } \\
\text { association of NOX2 subunit with } \\
\text { p47phox. Does not scavenge } \mathrm{O}_{2}^{-\bullet} \\
\text { generated by cell-free systems }\end{array}$ & None & {$[148,214]$} \\
\hline VAS3947 & $\begin{array}{l}\text { Triazolopyrimidine that decreased ROS } \\
\text { production in several cell lines with low } \\
\text { micro molar efficiency, irrespective of the } \\
\text { specific isoforms expressed; showed no } \\
\text { inhibitory effects against xanthine } \\
\text { oxidase-derived ROS or eNOS activity }\end{array}$ & None & {$[215]$} \\
\hline
\end{tabular}

Adapted from $[125,216]$.

eNOS: endothelial nitric oxide synthase; $\mathrm{IC}_{50}$ : half-maximal inhibitory concentration; Nox: NADPH oxidase; $\mathrm{O}_{2}{ }^{-\bullet}$ : superoxide; ROS: reactive oxygen species; SH3: Src homology 3; DPI: diphenyleneiodonium chloride; AEBSF: 4-(2-aminoethyl)-benzenesulfonyl fluoride; S178341: 4-dimethyl-2,3,5,6-triiodobenzene; VAS-2870: 3-benzyl-7-(2-benzoxazolyl) thio-1,2,3-triazolo (4,5-d) pyrimidine; SKF 525A: 2-diethylaminoethyl 2:2-diphenylvalerate hydrochloride.

effective against Nox2, Nox4, and Nox5 dependant NADPH oxidase-dependant activity. Apocynin has been shown to reverse activation of the NADPH oxidase system in rat kidneys induced by hydroxyl-l-proline (HLP) treatment even in the face of high levels of hyperoxaluria, revealing the role of Apocynin as an inhibitor as well as having antioxidant inductive activities [129].

The most frequently used inhibitor of NADPH oxidase is diphenyleneiodonium chloride (DPI), also known as dibenziodolium chloride. Its mode of action is by taking electrons from electron transporter and creating a radical which blocks the appropriate transporter of electrons through a covalent binding step [124]. Regarding NOX isoforms, the action of DPI appears to be nonspecific towards any isoform and it partially or completely inhibits different types of enzymes such as iNOS, xanthine oxidase, and NADPH oxidase [124].

\section{Summary}

In this review, we talk about renal injury caused by oxalate and calcium oxalate crystals due to hyperoxaluria. Oxalate and calcium oxalate can lead to renal injury due to disruption of membranes, ROS-induced oxidative stress, and mitochondrial dysfunction. We put the main emphasis on oxidative stress caused by ROS produced by different isoforms of NADPH oxidase as it has been found that these different isoforms of NADPH oxidase are one of the most important contributors of ROS and oxidative stress produced in the different subcellular localizations of the kidneys. These NADPH oxidase complexes play a crucial role in host defense, various signaling pathways leading to regulation of gene expression, and protein functions under normal conditions of oxidative balance. When this oxidative balance is disturbed 
due to environmental and/or physiological processes, the potential of the NADPH oxidases in inducing injury to both microorganisms and cells makes regulation essential, not only through normal physiological activities, but also exogenous inhibitors. Chemicals that inhibit generation of ROS provide considerable benefits over general antioxidants such as vitamin E, which appears to be less efficient due to various properties, including decreased bioavailability. It would seem, therefore, that in order to reduce the function and downstream effects of NADPH oxidase, a main focus should be on blocking the assembly of NADPH oxidase subunits. Various peptide and non-peptide inhibitors are known which mainly operate by disrupting the association of NADPH oxidase complex assembly. Special focus should be on targeting the organizer subunit, that is, $\mathrm{p} 47 \mathrm{phox}$ or the NOXO1 subunits. Other molecular subunits for therapy may be the activator subunits such as p67phox and NOXA1 along with Rac. Thus, the main focus should be to develop an inhibitor with increased efficiency and specificity of binding with the protein subunit. Comprehensive studies are needed on the molecular subunit structures to be targeted and their effects on interactions with other subunits present downstream in the NADPH oxidase complex.

\section{Acknowledgments}

This research was supported by National Institutes of Health Grant no. RO1-DK078602 and the University of Florida Center for the Study of Lithiasis.

\section{References}

[1] S. R. Khan, "Hyperoxaluria-induced oxidative stress and antioxidants for renal protection," Urological Research, vol. 33, no. 5, pp. 349-357, 2005.

[2] R. P. Holmes, H. O. Goodman, and D. G. Assimos, "Contribution of dietary oxalate to urinary oxalate excretion," Kidney International, vol. 59, no. 1, pp. 270-276, 2001.

[3] R. P. Holmes and D. G. Assimos, "The impact of dietary oxalate on kidney stone formation,” Urological Research, vol. 32, no. 5, pp. 311-316, 2004.

[4] R. P. Holmes, W. T. Ambrosius, and D. G. Assimos, "Dietary oxalate loads and renal oxalate handling," Journal of Urology, vol. 174, no. 3, pp. 943-947, 2005.

[5] J. Streit, L. C. Tran-Ho, and E. Königsberger, "Solubility of the three calcium oxalate hydrates in sodium chloride solutions and urine-like liquors," Monatshefte fur Chemie, vol. 129, no. 12, pp. 1225-1236, 1998.

[6] T. F. Knight, S. C. Sansom, H. O. Senekjian, and E. J. Weinman, "Oxalate secretion in the rat proximal tubule," The American Journal of Physiology, vol. 240, no. 4, pp. F295-F298, 1981.

[7] E. J. Weinman, S. J. Frankfurt, A. Ince, and S. Sansom, "Renal tubular transport of organic acids. Studies with oxalate and para-aminohippurate in the rat," The Journal of Clinical Investigation, vol. 61, no. 3, pp. 801-806, 1978.

[8] L. F. James, “Oxalate toxicosis," Clinical Toxicology, vol. 5, no. 2, pp. 231-243, 1972.

[9] H. E. Williams and T. R. Wandzilak, "Oxalate synthesis, transport and the hyperoxaluric syndromes," Journal of Urology, vol. 141, no. 3, pp. 742-749, 1989.
[10] W. G. Robertson and H. Hughes, "Importance of mild hyperoxaluria in the pathogenesis of urolithiasis-new evidence from studies in the Arabian Peninsula," Scanning Microscopy, vol. 7, no. 1, pp. 391-402, 1993.

[11] E. M. Worcester, J. H. Parks, A. P. Evan et al., "Renal function in patients with nephrolithiasis," Journal of Urology, vol. 176, no. 2, pp. 600-603, 2006.

[12] A. D. Rule, E. J. Bergstralh, L. J. Melton III et al., "Kidney stones and the risk for chronic kidney disease," Clinical Journal of the American Society of Nephrology, vol. 4, no. 4, pp. 804-811, 2009.

[13] B. Hoppe, B. B. Beck, and D. S. Milliner, "The primary hyperoxalurias," Kidney International, vol. 75, no. 12, pp. 12641271, 2009.

[14] B. A. Vervaet, A. Verhulst, P. C. D'Haese, and M. E. De Broe, "Nephrocalcinosis: new insights into mechanisms and consequences," Nephrology Dialysis Transplantation, vol. 24, no. 7, pp. 2030-2035, 2009.

[15] J. R. Asplin, "Hyperoxaluric calcium nephrolithiasis," Endocrinology and Metabolism Clinics of North America, vol. 31, no. 4, pp. 927-949, 2002.

[16] S. R. Marengo and A. M. P. Romani, "Oxalate in renal stone disease: the terminal metabolite that just won't go away," Nature Clinical Practice Nephrology, vol. 4, no. 7, pp. 368-377, 2008.

[17] A. E. Bobrowski and C. B. Langman, "The primary hyperoxalurias," Seminars in Nephrology, vol. 28, no. 2, pp. 152-162, 2008.

[18] E. Leumann and B. Hoppe, "The primary hyperoxalurias," Journal of the American Society of Nephrology, vol. 12, no. 9, pp. 1986-1993, 2001.

[19] C. G. Monico, M. Persson, G. C. Ford, G. Rumsby, and D. S. Milliner, "Potential mechanisms of marked hyperoxaluria not due to primary hyperoxaluria I or II," Kidney International, vol. 62 , no. 2, pp. 392-400, 2002.

[20] C. G. Monico, A. Weinstein, Z. Jiang et al., "Phenotypic and functional analysis of human SLC26A6 variants in patients with familial hyperoxaluria and calcium oxalate nephrolithiasis," American Journal of Kidney Diseases, vol. 52, no. 6, pp. 10961103, 2008.

[21] R. Belostotsky, E. Seboun, G. H. Idelson et al., "Mutations in DHDPSL are responsible for primary hyperoxaluria type III," American Journal of Human Genetics, vol. 87, no. 3, pp. 392-399, 2010.

[22] R. P. Holmes and M. Kennedy, "Estimation of the oxalate content of foods and daily oxalate intake," Kidney International, vol. 57, no. 4, pp. 1662-1667, 2000.

[23] B. Hoppe, G. von Unruh, N. Laube, A. Hesse, and H. Sidhu, "Oxalate degrading bacteria: new treatment option for patients with primary and secondary hyperoxaluria?" Urological Research, vol. 33, no. 5, pp. 372-375, 2005.

[24] R. Siener, D. Ebert, C. Nicolay, and A. Hesse, "Dietary risk factors for hyperoxaluria in calcium oxalate stone formers," Kidney International, vol. 63, no. 3, pp. 1037-1043, 2003.

[25] P. P. Singh, L. K. Kothari, D. C. Sharma, and S. N. Saxena, "Nutritional value of foods in relation to their oxalic acid content," American Journal of Clinical Nutrition, vol. 25, no. 11, pp. 1147-1152, 1972.

[26] G. E. von Unruh, S. Voss, T. Sauerbruch, and A. Hesse, "Dependence of oxalate absorption on the daily calcium intake," Journal of the American Society of Nephrology, vol. 15, no. 6, pp. 1567-1573, 2004.

[27] A. Hesse, W. Schneeberger, S. Engfeed, G. E. von Unruh, and T. Sauerbruch, "Intestinal hyperabsorption of oxalate in 
calcium oxalate stone formers: application of a new test with [13C2] oxalate," Journal of the American Society of Nephrology, vol. 10, supplement 14, pp. S329-S333, 1999.

[28] S. Voss, A. Hesse, D. J. Zimmermann, T. Sauerbruch, and G. E. von Unruh, "Intestinal oxalate absorption is higher in idiopathic calcium oxalate stone formers than in healthy controls: measurements with the [(13)C2]oxalate absorption test," Journal of Urology, vol. 175, no. 5, pp. 1711-1715, 2006.

[29] M. Lindsjo, B. G. Danielson, B. Fellstrom, and S. Ljunghall, "Intestinal oxalate and calcium absorption in recurrent renal stone formers and healthy subjects," Scandinavian Journal of Urology and Nephrology, vol. 23, no. 1, pp. 55-59, 1989.

[30] J. Knight, R. P. Holmes, and D. G. Assimos, "Intestinal and renal handling of oxalate loads in normal individuals and stone formers," Urological Research, vol. 35, no. 3, pp. 111-117, 2007.

[31] E. M. Worcester, "Stones from bowel disease," Endocrinology and Metabolism Clinics of North America, vol. 31, no. 4, pp. 979999, 2002.

[32] S. Thamilselvan and S. R. Khan, "Oxalate and calcium oxalate crystals are injurious to renal epithelial cells: results of in vivo and in vitro studies," Journal of Nephrology, vol. 11, supplement 1, pp. 66-69, 1998.

[33] S. R. Khan, J. M. Johnson, A. B. Peck, J. G. Cornelius, and P. A. Glenton, "Expression of osteopontin in rat kidneys: induction during ethylene glycol induced calcium oxalate nephrolithiasis," Journal of Urology, vol. 168, no. 3, pp. 1173-1181, 2002.

[34] S. Thamilselvan, S. R. Khan, and M. Menon, "Oxalate and calcium oxalate mediated free radical toxicity in renal epithelial cells: effect of antioxidants," Urological Research, vol. 31, no. 1, pp. 3-9, 2003.

[35] K. McMartin, "Are calcium oxalate crystals involved in the mechanism of acute renal failure in ethylene glycol poisoning Ethylene glycol renal toxicity mechanism," Clinical Toxicology, vol. 47, no. 9, pp. 859-869, 2009.

[36] C. Miller, L. Kennington, R. Cooney et al., "Oxalate toxicity in renal epithelial cells: characteristics of apoptosis and necrosis," Toxicology and Applied Pharmacology, vol. 162, no. 2, pp. 132$141,2000$.

[37] A. Bhandari, S. Koul, A. Sekhon et al., "Effects of oxalate on HK2 cells, a line of proximal tubular epithelial cells from normal human kidney," Journal of Urology, vol. 168, no. 1, pp. 253-259, 2002.

[38] J. Burgess and D. N. Drasdo, "Solubilities of calcium salts of dicarboxylic acids in methanol-water mixtures; transfer chemical potentials of dicarboxylate anions," Polyhedron, vol. 12, no. 24, pp. 2905-2911, 1993.

[39] S. Ebisuno, H. Koul, M. Menon, and C. Scheid, "Oxalate transport in a line of porcine renal epithelial cells-LLC-PK1 cells," Journal of Urology, vol. 152, no. 1, pp. 237-242, 1994.

[40] H. Koul, S. Ebisuno, L. Renzulli, M. Yanagawa, M. Menon, and C. Scheid, "Polarized distribution of oxalate transport systems in LLC-PK1 cells, a line of renal epithelial cells," American Journal of Physiology, vol. 266, no. 2, pp. F266-F274, 1994.

[41] M. Hatch, R. W. Freel, and N. D. Vaziri, "Intestinal excretion of oxalate in chronic renal failure," Journal of the American Society of Nephrology, vol. 5, no. 6, pp. 1339-1343, 1994.

[42] M. W. Bigelow, J. H. Wiessner, J. G. Kleinman, and N. S. Mandel, "Surface exposure of phosphatidylserine increases calcium oxalate crystal attachment to IMCD cells," American Journal of Physiology, vol. 272, no. 1, pp. F55-F62, 1997.
[43] L. C. Cao, T. Honeyman, J. Jonassen, and C. Scheid, "Oxalateinduced ceramide accumulation in Madin-Darby canine kidney and LLC-PK1 cells," Kidney International, vol. 57, no. 6, pp. 2403-2411, 2000.

[44] L. C. Cao, J. Jonassen, T. W. Honeyman, and C. Scheid, “Oxalateinduced redistribution of phosphatidylserine in renal epithelial cells: implications for kidney stone disease," American Journal of Nephrology, vol. 21, no. 1, pp. 69-77, 2001.

[45] C. Guo, T. A. Cenac, Y. Li, and K. E. McMartin, "Calcium oxalate, and not other metabolites, is responsible for the renal toxicity of ethylene glycol," Toxicology Letters, vol. 173, no. 1, pp. 8-16, 2007.

[46] O. Sareila, T. Kelkka, A. Pizzolla et al., "NOX2 complex-derived ROS as immune regulators," Antioxidants \& Redox Signaling, vol. 15, no. 8, pp. 2197-2208, 2011.

[47] B. Descamps-Latscha, T. Drüeke, and V. Witko-Sarsat, "Dialysis-induced oxidative stress: biological aspects, clinical consequences, and therapy," Seminars in Dialysis, vol. 14, no. 3, pp. 193-199, 2001.

[48] C. C. Winterbourn, "Reconciling the chemistry and biology of reactive oxygen species," Nature Chemical Biology, vol. 4, no. 5, pp. 278-286, 2008.

[49] M. P. Kao, D. S. Ang, A. Pall, and A. D. Struthers, "Oxidative stress in renal dysfunction: mechanisms, clinical sequelae and therapeutic options," Journal of Human Hypertension, vol. 24, no. 1, pp. 1-8, 2010.

[50] Y. C. Hou, A. Janczuk, and P. G. Wang, "Current trends in the development of nitric oxide donors," Current Pharmaceutical Design, vol. 5, no. 6, pp. 417-441, 1999.

[51] S. J. Klebanoff, "Myeloperoxidase: friend and foe," Journal of Leukocyte Biology, vol. 77, no. 5, pp. 598-625, 2005.

[52] D. P. Jones, "Radical-free biology of oxidative stress," American Journal of Physiology, vol. 295, no. 4, pp. 849-868, 2008.

[53] S. R. Thomas, P. K. Witting, and G. R. Drummond, "Redox control of endothelial function and dysfunction: molecular mechanisms and therapeutic opportunities," Antioxidants \& Redox Signaling, vol. 10, no. 10, pp. 1713-1765, 2008.

[54] R. Stocker and J. F. Keaney, "Role of oxidative modifications in atherosclerosis," Physiological Reviews, vol. 84, no. 4, pp. 13811478, 2004.

[55] U. Forstermann, "Nitric oxide and oxidative stress in vascular disease," Pflügers Archiv, vol. 459, no. 6, pp. 923-939, 2010.

[56] N. V. Blough and O. C. Zafiriou, "Reaction of superoxide with nitric oxide to form peroxonitrite in alkaline aqueous solution," Inorganic Chemistry, vol. 24, no. 22, pp. 3502-3504, 1985.

[57] R. J. Gryglewski, R. M. J. Palmer, and S. Moncada, "Superoxide anion is involved in the breakdown of endothelium-derived vascular relaxing factor," Nature, vol. 320, no. 6061, pp. 454-456, 1986.

[58] C. Szabo, H. Ischiropoulos, and R. Radi, "Peroxynitrite: biochemistry, pathophysiology and development of therapeutics," Nature Reviews Drug Discovery, vol. 6, no. 8, pp. 662-680, 2007.

[59] D. G. Harrison, W. Chen, S. Dikalov, and L. Li, "Regulation of endothelial cell tetrahydrobiopterin. Pathophysiological and therapeutic implications," Advances in Pharmacology, vol. 60, pp. 116-132, 2010.

[60] J. B. Laursen, M. Somers, S. Kurz et al., "Endothelial regulation of vasomotion in ApoE-deficient mice: implications for interactions between peroxynitrite and tetrahydrobiopterin," Circulation, vol. 103, no. 9, pp. 1282-1288, 2001. 
[61] W. Droge, "Free radicals in the physiological control of cell function," Physiological Reviews, vol. 82, no. 1, pp. 47-95, 2002.

[62] J. Anrather, G. Racchumi, and C. Iadecola, "NF- $\kappa$ B regulates phagocytic NADPH oxidase by inducing the expression of gp91phox," The Journal of Biological Chemistry, vol. 281, no. 9, pp. 5657-5667, 2006.

[63] R. Dworakowski, S. P. Alom-Ruiz, and A. M. Shah, "NADPH oxidase-derived reactive oxygen species in the regulation of endothelial phenotype," Pharmacological Reports, vol. 60, no. 1, pp. 21-28, 2008.

[64] B. Lassegue and K. K. Griendling, "NADPH oxidases: functions and pathologies in the vasculature," Arteriosclerosis, Thrombosis, and Vascular Biology, vol. 30, no. 4, pp. 653-661, 2001.

[65] F. Martinon, "Signaling by ROS drives inflammasome activation," European Journal of Immunology, vol. 40, no. 3, pp. 616$619,2010$.

[66] T. Chabrashvili, C. Kitiyakara, J. Blau et al., "Effects of ANG II type 1 and 2 receptors on oxidative stress, renal NADPH oxidase, and SOD expression," American Journal of Physiology, vol. 285, no. 1, pp. R117-R124, 2003.

[67] W. J. Welch, J. Blau, H. Xie et al., "Angiotensin-induced defects in renal oxygenation: role of oxidative stress," American Journal of Physiology, vol. 288, no. 1, pp. 22-28, 2005.

[68] H. S. Huang, M. C. Ma, C. F. Chen, and J. Chen, "Lipid peroxidation and its correlations with urinary levels of oxalate, citric acid, and osteopontin in patients with renal calcium oxalate stones," Urology, vol. 62, no. 6, pp. 1123-1128, 2003.

[69] K. Tungsanga, P. Sriboonlue, P. Futrakul, C. Yachantha, and P. Tosukhowong, "Renal tubular cell damage and oxidative stress in renal stone patients and the effect of potassium citrate treatment," Urological Research, vol. 33, no. 1, pp. 65-69, 2005.

[70] W. J. Welch, A. Tojo, and C. S. Wilcox, "Roles of NO and oxygen radicals in tubuloglomerular feedback in SHR," American Journal of Physiology, vol. 278, no. 5, pp. F769-F776, 2000.

[71] H. M. Bosse and S. Bachmann, "Immunohistochemically detected protein nitration indicates sites of renal nitric oxide release in Goldblatt hypertension," Hypertension, vol. 30, no. 4, pp. 948-952, 1997.

[72] A. P. Zou, N. Li, and A. W. Cowley Jr., "Production and actions of superoxide in the renal medulla," Hypertension, vol. 37, no. 2, pp. 547-553, 2001.

[73] M. L. Onozato, A. Tojo, A. Goto, T. Fujita, and C. S. Wilcox, "Oxidative stress and nitric oxide synthase in rat diabetic nephropathy: effects of ACEI and ARB," Kidney International, vol. 61, no. 1, pp. 186-194, 2002.

[74] T. L. Leto, S. Morand, D. Hurt, and T. Ueyama, “Targeting and regulation of reactive oxygen species generation by Nox family NADPH oxidases," Antioxidants \& Redox Signaling, vol. 11, no. 10, pp. 2607-2619, 2009.

[75] L. Serrander, L. Cartier, K. Bedard et al., "NOX4 activity is determined by mRNA levels and reveals a unique pattern of ROS generation," Biochemical Journal, vol. 406, no. 1, pp. 105114, 2007.

[76] S. I. Dikalov, A. E. Dikalova, A. T. Bikineyeva, H. H. H. W. Schmidt, D. G. Harrison, and K. K. Griendling, "Distinct roles of Noxl and Nox4 in basal and angiotensin II-stimulated superoxide and hydrogen peroxide production," Free Radical Biology and Medicine, vol. 45, no. 9, pp. 1340-1351, 2008.

[77] B. T. Kawahara, M. T. Quinn, and J. D. Lambeth, "Molecular evolution of the reactive oxygen-generating NADPH oxidase (Nox/Duox) family of enzymes," BMC Evolutionary Biology, vol. 7, article 109, 2007.
[78] K. Bedard and K. H. Krause, "The NOX family of ROSgenerating NADPH oxidases: physiology and pathophysiology," Physiological Reviews, vol. 87, no. 1, pp. 245-313, 2007.

[79] W. Chamulitrat, R. Schmidt, P. Tomakidi et al., "Association of gp91phox homolog Noxl with anchorage-independent growth and MAP kinase-activation of transformed human keratinocytes," Oncogene, vol. 22, no. 38, pp. 6045-6053, 2003.

[80] N. Coant, S. B. Mkaddem, E. Pedruzzi et al., "NADPH oxidase 1 modulates WNT and NOTCH1 signaling to control the fate of proliferative progenitor cells in the colon," Molecular and Cellular Biology, vol. 30, no. 11, pp. 2636-2650, 2010.

[81] W. M. Nauseef, "Nox enzymes in immune cells," Seminars in Immunopathology, vol. 30, no. 3, pp. 195-208, 2008.

[82] S. F. Moore and A. B. MacKenzie, "NADPH oxidase NOX2 mediates rapid cellular oxidation following ATP stimulation of endotoxin-primed macrophages," Journal of Immunology, vol. 183, no. 5, pp. 3302-3308, 2009.

[83] R. L. McCaffrey, J. T. Schwartz, S. R. Lindemann et al., "Multiple mechanisms of NADPH oxidase inhibition by type A and type B Francisella tularensis," Journal of Leukocyte Biology, vol. 88, no. 4, pp. 791-805, 2010.

[84] D. Mukherjea, S. Jajoo, K. Sheehan et al., "NOX3 NADPH oxidase couples transient receptor potential vanilloid 1 to signal transducer and activator of transcription 1-mediated inflammation and hearing loss," Antioxidants \& Redox Signaling, vol. 14, no. 6, pp. 999-1010, 2011.

[85] K. Schroder, K. Wandzioch, I. Helmcke et al., "Nox4 acts as a switch between differentiation and proliferation in preadipocytes," Arteriosclerosis, Thrombosis, and Vascular Biology, vol. 29, no. 2, pp. 239-245, 2009.

[86] S. Pendyala, I. A. Gorshkova, P. V. Usatyuk et al., "Role of Nox4 and Nox 2 in hyperoxia-induced reactive oxygen species generation and migration of human lung endothelial cells," Antioxidants \& Redox Signaling, vol. 11, no. 4, pp. 747-764, 2009.

[87] A. N. Lyle, N. N. Deshpande, Y. Taniyama et al., "Poldip2, a novel regulator of Nox 4 and cytoskeletal integrity in vascular smooth muscle cells," Circulation Research, vol. 105, no. 3, pp. 249-259, 2009.

[88] J. I. Jun and L. F. Lau, "The matricellular protein CCN1 induces fibroblast senescence and restricts fibrosis in cutaneous wound healing," Nature Cell Biology, vol. 12, no. 7, pp. 676-685, 2010.

[89] J. Si, J. Behar, J. Wands et al., "STAT5 mediates PAF-induced NADPH oxidase NOX5-S expression in Barrett's esophageal adenocarcinoma cells," American Journal of Physiology, vol. 294, no. 1, pp. 174-183, 2008.

[90] D. B. Jay, C. A. Papaharalambus, B. Seidel-Rogol, A. E. Dikalova, B. Lassègue, and K. K. Griendling, "Nox5 mediates PDGFinduced proliferation in human aortic smooth muscle cells," Free Radical Biology and Medicine, vol. 45, no. 3, pp. 329-335, 2008.

[91] A. S. Kamiguti, L. Serrander, K. Lin et al., "Expression and activity of NOX5 in the circulating malignant B cells of hairy cell leukemia," Journal of Immunology, vol. 175, no. 12, pp. 84248430, 2005.

[92] J. Si, X. Fu, J. Behar et al., "NADPH oxidase NOX5-S mediates acid-induced cyclooxygenase-2 expression via activation of NF$\kappa \mathrm{B}$ in Barrett's esophageal adenocarcinoma cells," The Journal of Biological Chemistry, vol. 282, no. 22, pp. 16244-16255, 2007.

[93] H. Fischer, "Mechanisms and function of DUOX in epithelia of the lung," Antioxidants \& Redox Signaling, vol. 11, no. 10, pp. 2453-2465, 2009. 
[94] A. Allaoui, A. Botteaux, J. E. Dumont, C. Hoste, and X. De Deken, "Dual oxidases and hydrogen peroxide in a complex dialogue between host mucosae and bacteria," Trends in Molecular Medicine, vol. 15, no. 12, pp. 571-579, 2009.

[95] P. S. Gill and C. S. Wilcox, "NADPH oxidases in the kidney," Antioxidants \& Redox Signaling, vol. 8, no. 9-10, pp. 1597-1607, 2006.

[96] J. K. Guo and L. G. Cantley, "Cellular maintenance and repair of the kidney," Annual Review of Physiology, vol. 72, pp. 357-376, 2010.

[97] D. Wang, Y. Chen, T. Chabrashvili et al., "Role of oxidative stress in endothelial dysfunction and enhanced responses to angiotensin II of afferent arterioles from rabbits infused with angiotensin II," Journal of the American Society of Nephrology, vol. 14, no. 11, pp. 2783-2789, 2003.

[98] T. Chabrashvili, A. Tojo, M. L. Onozato et al., "Expression and cellular localization of classic NADPH oxidase subunits in the spontaneously hypertensive rat kidney," Hypertension, vol. 39, no. 2, pp. 269-274, 2002.

[99] H. H. Radeke, A. R. Cross, J. T. Hancock et al., "Functional expression of NADPH oxidase components ( $\alpha$ - and $\beta$-subunits of cytochrome b558 and $45-\mathrm{kDa}$ flavoprotein) by intrinsic human glomerular mesangial cells," The Journal of Biological Chemistry, vol. 266, no. 31, pp. 21025-21029, 1991.

[100] S. A. Jones, J. T. Hancock, O. T. G. Jones, A. Neubauer, and N. Topley, "The expression of NADPH oxidase components in human glomerular mesangial cells: detection of protein and mRNA for p47phox, p67phox, and p22phox," Journal of the American Society of Nephrology, vol. 5, no. 7, pp. 1483-1491, 1995.

[101] Y. Gorin, K. Block, J. Hernandez et al., "Nox4 NAD(P)H oxidase mediates hypertrophy and fibronectin expression in the diabetic kidney," The Journal of Biological Chemistry, vol. 280, no. 47, pp. 39616-39626, 2005.

[102] Y. Gorin, J. M. Ricono, N. H. Kim, B. Bhandari, G. G. Choudhury, and H. E. Abboud, "Nox4 mediates angiotensin IIinduced activation of Akt/protein kinase B in mesangial cells," American Journal of Physiology, vol. 285, no. 2, pp. F219-F229, 2003.

[103] N. Li, F. X. Yi, J. L. Spurrier, C. A. Bobrowitz, and A. P. Zou, "Production of superoxide through NADH oxidase in thick ascending limb of Henle's loop in rat kidney," American Journal of Physiology, vol. 282, no. 6, pp. F1111-F1119, 2002.

[104] S. Greiber, T. Munzel, S. Kastner et al., "NAD(P)H oxidase activity in cultured human podocytes: effects of adenosine triphosphate," Kidney International, vol. 53, no. 3, pp. 654-663, 1998.

[105] M. Geiszt, J. B. Kopp, P. Varnai et al., "Identification of renox, an NAD $(\mathrm{P}) \mathrm{H}$ oxidase in kidney," Proceedings of the National Academy of Sciences of the United States of America, vol. 97, no. 14, pp. 8010-8014, 2000.

[106] A. Shiose, J. Kuroda, K. Tsuruya et al., "A novel superoxideproducing $\mathrm{NAD}(\mathrm{P}) \mathrm{H}$ oxidase in kidney," The Journal of Biological Chemistry, vol. 276, no. 2, pp. 1417-1423, 2001.

[107] P. Modlinger, T. Chabrashvili, P. S. Gill et al., "RNA silencing in vivo reveals role of $\mathrm{p} 22 \mathrm{phox}$ in rat angiotensin slow pressor response," Hypertension, vol. 47, no. 2, pp. 238-244, 2006.

[108] C. Kitiyakara, T. Chabrashvili, Y. Chen et al., "Salt intake, oxidative stress, and renal expression of NADPH oxidase and superoxide dismutase," Journal of the American Society of Nephrology, vol. 14, no. 11, pp. 2775-2782, 2003.
[109] B. M. Babior, J. D. Lambeth, and W. Nauseef, "The neutrophil NADPH oxidase," Archives of Biochemistry and Biophysics, vol. 397, no. 2, pp. 342-344, 2002.

[110] F. J. Miller, M. Filali, G. J. Huss et al., "Cytokine activation of nuclear factor $\kappa \mathrm{B}$ in vascular smooth muscle cells requires signaling endosomes containing Noxl and ClC-3," Circulation Research, vol. 101, no. 7, pp. 663-671, 2007.

[111] J. D. Lambeth, "NOX enzymes and the biology of reactive oxygen," Nature Reviews Immunology, vol. 4, no. 3, pp. 181-189, 2004.

[112] B. Lassègue, D. Sorescu, K. Szöcs et al., "Novel gp91phox homologues in vascular smooth muscle cells: Noxl mediates angiotensin II-induced superoxide formation and redoxsensitive signaling pathways," Circulation Research, vol. 88, no. 9, pp. 888-894, 2001.

[113] P. J. Pagano, S. J. Chanock, D. A. Siwik, W. S. Colucci, and J. K. Clark, "Angiotensin II induces p67(phox) mRNA expression and NADPH oxidase superoxide generation in rabbit aortic adventitial fibroblasts," Hypertension, vol. 32, no. 2, pp. 331-337, 1998.

[114] M. E. Cifuentes, F. E. Rey, O. A. Carretero, and P. J. Pagano, "Upregulation of p67(phox) and gp91(phox) in aortas from angiotensin II-infused mice," American Journal of Physiology, vol. 279, no. 5, pp. H2234-H2240, 2000.

[115] S. Thamilselvan and R. Selvam, "Effect of vitamin E and mannitol on renal calcium oxalate retention in experimental nephrolithiasis," Indian Journal of Biochemistry and Biophysics, vol. 34, no. 3, pp. 319-323, 1997.

[116] M. Santhosh Kumar and R. Selvam, "Supplementation of vitamin $\mathrm{E}$ and selenium prevents hyperoxaluria in experimental urolithic rats," Journal of Nutritional Biochemistry, vol. 14, no. 6, pp. 306-313, 2003.

[117] R. Selvam and V. Ravichandran, "Restoration of tissue antioxidants and prevention of renal stone deposition in vitamin B6 deficient rats fed with vitamin E or methionine," Indian Journal of Experimental Biology, vol. 31, no. 11, pp. 882-887, 1993.

[118] A. Muthukumar and R. Selvam, "Role of glutathione on renal mitochondrial status in hyperoxaluria," Molecular and Cellular Biochemistry, vol. 185, no. 1-2, pp. 77-84, 1998.

[119] J. Bleys, E. R. Miller III, R. Pastor-Barriuso et al., "Vitaminmineral supplementation and the progression of atherosclerosis: a meta-analysis of randomized controlled trials," American Journal of Clinical Nutrition, vol. 84, no. 4, pp. 880-887, 2006.

[120] D. P. Vivekananthan, M. S. Penn, S. K. Sapp, A. Hsu, and E. J. Topol, "Use of antioxidant vitamins for the prevention of cardiovascular disease: meta-analysis of randomised trials," The Lancet, vol. 361, no. 9374, pp. 2017-2023, 2003.

[121] E. L. Schiffrin, "Antioxidants in hypertension and cardiovascular disease," Molecular Interventions, vol. 10, no. 6, pp. 354-362, 2010.

[122] R. Kissner, T. Nauser, P. Bugnon, P. G. Lye, and W. H. Koppenol, "Formation and properties of peroxynitrite as studied by laser flash photolysis, high-pressure stopped-flow technique, pulse radiolysis," Chemical Research in Toxicology, vol. 10, no. 11, pp. 1285-1292, 1997.

[123] N. Gotoh and E. Niki, "Rates of interactions of superoxide with vitamin $\mathrm{E}$, vitamin $\mathrm{C}$ and related compounds as measured by chemiluminescence," Biochimica et Biophysica Acta, vol. 1115, no. 3, pp. 201-207, 1992.

[124] S. Selemidis, C. G. Sobey, K. Wingler, H. H. H. W. Schmidt, and G. R. Drummond, "NADPH oxidases in the vasculature: 
molecular features, roles in disease and pharmacological inhibition," Pharmacology and Therapeutics, vol. 120, no. 3, pp. 254291, 2008.

[125] P. Kleniewska, A. Piechota, B. Skibska et al., "The NADPH oxidase family and its inhibitors," Archivum Immunologiae et Therapiae Experimentalis, vol. 60, no. 4, pp. 277-294, 2012.

[126] J. Stefanska and R. Pawliczak, "Apocynin: molecular aptitudes," Mediators of Inflammation, vol. 2008, Article ID 106507, 10 pages, 2008.

[127] D. K. Johnson, K. J. Schillinger, D. M. Kwait et al., "Inhibition of NADPH oxidase activation in endothelial cells by orthomethoxy-substituted catechols," Endothelium, vol. 9, no. 3, pp. 191-203, 2002.

[128] S. H. M. Ellmark, G. J. Dusting, M. N. Tang Fui, N. GuzzoPernell, and G. R. Drummond, "The contribution of Nox4 to NADPH oxidase activity in mouse vascular smooth muscle," Cardiovascular Research, vol. 65, no. 2, pp. 495-504, 2005.

[129] S. Joshi, B. T. Saylor, W. Wang et al., "Apocynin-treatment reverses hyperoxaluria induced changes in NADPH oxidase system expression in rat kidneys: a transcriptional study," PLoS One, vol. 7, no. 10, Article ID e47738, 2012.

[130] J. M. Simons, L. A. Hart, H. van Dijk, F. C. Fischer, K. T. D. De Silva, and R. P. Labadie, "Immunodulatory compounds from Picrorhiza kurroa: isolation and characterization of two anti-complementary polymeric fractions from an aqueous root extract," Journal of Ethnopharmacology, vol. 26, no. 2, pp. 169$182,1989$.

[131] J. Stolk, T. J. Hiltermann, J. H. Dijkman, and A. J. Verhoeven, "Characteristics of the inhibition of NADPH oxidase activation in neutrophils by apocynin, a methoxy-substituted catechol," American Journal of Respiratory Cell and Molecular Biology, vol. 11, no. 1, pp. 95-102, 1994.

[132] B. A. Hart, J. M. Simons, S. Knaan-Shanzer, N. P. M. Bakker, and R. P. Labadie, "Antiarthritic activity of the newly developed neutrophil oxidative burst antagonist apocynin," Free Radical Biology and Medicine, vol. 9, no. 2, pp. 127-131, 1990.

[133] V. B. O’Donnell, D. G. Tew, O. T. G. Jones, and P. J. England, "Studies on the inhibitory mechanism of iodonium compounds with special reference to neutrophil NADPH oxidase," Biochemical Journal, vol. 290, no. 1, pp. 41-49, 1993.

[134] V. B. O’Donnell, G. C. M. Smith, and O. T. G. Jones, "Involvement of phenyl radicals in iodonium compound inhibition of flavoenzymes," Molecular Pharmacology, vol. 46, no. 4, pp. 778$785,1994$.

[135] D. J. Stuehr, O. A. Fasehun, N. S. Kwon et al., "Inhibition of macrophage and endothelial cell nitric oxide synthase by diphenyleneiodonium and its analogs," FASEB Journal, vol. 5, no. 1, pp. 98-103, 1991.

[136] S. J. Gatley and H. S. A. Sherratt, "The effects of diphenyleneiodonium on mitochondrial reactions. Relation of binding of diphenylene[125I]iodonium to mitochondria to the extent of inhibition of oxygen uptake," Biochemical Journal, vol. 158, no. 2, pp. 307-315, 1976.

[137] A. R. Cross, J. F. Parkinson, and O. T. G. Jones, “The superoxidegenerating oxidase of leucocytes. NADPH-dependent reduction of flavin and cytochrome b in solubilized preparations," Biochemical Journal, vol. 223, no. 2, pp. 337-344, 1984.

[138] A. R. Cross and O. T. G. Jones, "The effect of the inhibitor diphenylene iodonium on the superoxide-generating system of neutrophils. Specific labelling of a component polypeptide of the oxidase," Biochemical Journal, vol. 237, no. 1, pp. 111-116, 1986.
[139] R. Brandsch and V. Bichler, "Studies in vitro on the flavinylation of 6-hydroxy-D-nicotine oxidase," European Journal of Biochemistry, vol. 160, no. 2, pp. 285-289, 1986.

[140] V. Diatchuk, O. Lotan, V. Koshkin, P. Wikstroem, and E. Pick, "Inhibition of NADPH oxidase activation by 4-(2-aminoethyl)benzenesulfonyl fluoride and related compounds," The Journal of Biological Chemistry, vol. 272, no. 20, pp. 13292-13301, 1997.

[141] A. Rossary, K. Arab, and J. P. Steghens, "Polyunsaturated fatty acids modulate NOX 4 anion superoxide production in human fibroblasts," Biochemical Journal, vol. 406, no. 1, pp. 77-83, 2007.

[142] C. Fan, M. Katsuyama, T. Nishinaka, and C. Yabe-Nishimura, "Transactivation of the EGF receptor and a PI3 kinase-ATF-1 pathway is involved in the upregulation of NOX1, a catalytic subunit of NADPH oxidase," FEBS Letters, vol. 579, no. 5, pp. 1301-1305, 2005.

[143] J. Shi, C. R. Ross, T. L. Leto, and F. Blecha, “PR-39, a proline-rich antibacterial peptide that inhibits phagocyte NADPH oxidase activity by binding to Src homology 3 domains of p47phox," Proceedings of the National Academy of Sciences of the United States of America, vol. 93, no. 12, pp. 6014-6018, 1996.

[144] A. J. Cayatte, A. Rupin, J. Oliver-Krasinski et al., "S17834, a new inhibitor of cell adhesion and atherosclerosis that targets nadph oxidase," Arteriosclerosis, Thrombosis, and Vascular Biology, vol. 21, no. 10, pp. 1577-1584, 2001.

[145] C. Stielow, R. A. Catar, G. Muller et al., "Novel Nox inhibitor of oxLDL-induced reactive oxygen species formation in human endothelial cells," Biochemical and Biophysical Research Communications, vol. 344, no. 1, pp. 200-205, 2006.

[146] H. ten Freyhaus, M. Huntgeburth, K. Wingler et al., "Novel Nox inhibitor VAS2870 attenuates PDGF-dependent smooth muscle cell chemotaxis, but not proliferation," Cardiovascular Research, vol. 71, no. 2, pp. 331-341, 2006.

[147] F. R. DeLeo, L. Yu, J. B. Burritt et al., "Mapping sites of interaction of $\mathrm{p} 47$-phox and flavocytochrome $\mathrm{b}$ with randomsequence peptide phage display libraries," Proceedings of the National Academy of Sciences of the United States of America, vol. 92, no. 15, pp. 7110-7114, 1995.

[148] F. E. Rey, M. E. Cifuentes, A. Kiarash, M. T. Quinn, and P. J. Pagano, "Novel competitive inhibitor of NAD $(\mathrm{P}) \mathrm{H}$ oxidase assembly attenuates vascular $\mathrm{O} 2$ - and systolic blood pressure in mice," Circulation Research, vol. 89, no. 5, pp. 408-414, 2001.

[149] G. M. Bokoch and V. Prossnitz, "Isoprenoid metabolism is required for stimulation of the respiratory burst oxidase of HL60 cells," The Journal of Clinical Investigation, vol. 89, no. 2, pp. 402-408, 1992.

[150] S. Wassmann, U. Laufs, K. Muller et al., "Cellular antioxidant effects of atorvastatin in vitro and in vivo," Arteriosclerosis, Thrombosis, and Vascular Biology, vol. 22, no. 2, pp. 300-305, 2002.

[151] S. Rajagopalan, S. Kurz, T. Münzel et al., "Angiotensin IImediated hypertension in the rat increases vascular superoxide production via membrane NADH/NADPH oxidase activation: contribution to alterations of vasomotor tone," The Journal of Clinical Investigation, vol. 97, no. 8, pp. 1916-1923, 1996.

[152] R. P. Mason, L. Kalinowski, R. F. Jacob, A. M. Jacoby, and T. Malinski, "Nebivolol reduces nitroxidative stress and restores nitric oxide bioavailability in endothelium of black Americans," Circulation, vol. 112, no. 24, pp. 3795-3801, 2005.

[153] H. Mollnau, E. Schulz, A. Daiber et al., "Nebivolol prevents vascular NOS III uncoupling in experimental hyperlipidemia and inhibits NADPH oxidase activity in inflammatory cells," 
Arteriosclerosis, Thrombosis, and Vascular Biology, vol. 23, no. 4, pp. 615-621, 2003.

[154] M. Oelze, A. Daiber, R. P. Brandes et al., "Nebivolol inhibits superoxide formation by NADPH oxidase and endothelial dysfunction in angiotensin II-treated rats," Hypertension, vol. 48, no. 4, pp. 677-684, 2006.

[155] R. Troost, E. Schwedhelm, S. Rojczyk, D. Tsikas, and J. C. Frolich, "Nebivolol decreases systemic oxidative stress in healthy volunteers," British Journal of Clinical Pharmacology, vol. 50, no. 4, pp. 377-379, 2000.

[156] C. Coméra, K. André, J. Laffitte, X. Collet, P. Galtier, and I. Maridonneau-Parini, "Gliotoxin from Aspergillus fumigatus affects phagocytosis and the organization of the actin cytoskeleton by distinct signalling pathways in human neutrophils," Microbes and Infection, vol. 9, no. 1, pp. 47-54, 2007.

[157] T. Kawahara, Y. Kuwano, S. Teshima-Kondo et al., "Role of nicotinamide adenine dinucleotide phosphate oxidase 1 in oxidative burst response to Toll-like receptor 5 signaling in large intestinal epithelial cells," Journal of Immunology, vol. 172, no. 5, pp. 3051-3058, 2004.

[158] Y. O. Kweon, Y. H. Paik, B. Schnabl, T. Qian, J. J. Lemasters, and D. A. Brenner, "Gliotoxin-mediated apoptosis of activated human hepatic stellate cells," Journal of Hepatology, vol. 39, no. 1, pp. 38-46, 2003.

[159] S. Tsunawaki, L. S. Yoshida, S. Nishida, T. Kobayashi, and T. Shimoyama, "Fungal metabolite gliotoxin inhibits assembly of the human respiratory burst NADPH oxidase," Infection and Immunity, vol. 72, no. 6, pp. 3373-3382, 2004.

[160] L. S. Yoshida, S. Abe, and S. Tsunawaki, "Fungal gliotoxin targets the onset of superoxide-generating NADPH oxidase of human neutrophils," Biochemical and Biophysical Research Communications, vol. 268, no. 3, pp. 716-723, 2000.

[161] P. Sehr, G. Joseph, H. Genth, I. Just, E. Pick, and K. Aktories, "Glucosylation and ADP ribosylation of Rho proteins: effects on nucleotide binding, GTPase activity, and effector coupling," Biochemistry, vol. 37, no. 15, pp. 5296-5304, 1998.

[162] J. A. Holland, J. W. Meyer, M. M. Chang, R. W. O’Donnell, D. K. Johnson, and L. M. Ziegler, "Thrombin stimulated reactive oxygen species production in cultured human endothelial cells," Endothelium, vol. 6, no. 2, pp. 113-121, 1998.

[163] Y. Ozaki, T. Ohashi, and Y. Niwa, "A comparative study on the effects of inhibitors of the lipoxygenase pathway on neutrophil function. Inhibitory effects on neutrophil function may not be attributed to inhibition of the lipoxygenase pathway," Biochemical Pharmacology, vol. 35, no. 20, pp. 3481-3488, 1986.

[164] S. Tsunawaki and C. F. Nathan, "Release of arachidonate and reduction of oxygen. Independent metabolic bursts of the mouse peritoneal macrophage," The Journal of Biological Chemistry, vol. 261, no. 25, pp. 11563-11570, 1986.

[165] J. A. Holland, J. W. Meyer, M. E. Schmitt et al., "Low-density lipoprotein stimulated peroxide production and endocytosis in cultured human endothelial cells: mechanisms of action," Endothelium, vol. 5, no. 3, pp. 191-207, 1997.

[166] D. Bonnefont-Rousselot, B. Raji, S. Walrand et al., "An intracellular modulation of free radical production could contribute to the beneficial effects of metformin towards oxidative stress," Metabolism, vol. 52, no. 5, pp. 586-589, 2003.

[167] M. Mahrouf, N. Ouslimani, J. Peynet et al., "Metformin reduces angiotensin-mediated intracellular production of reactive oxygen species in endothelial cells through the inhibition of protein kinase C," Biochemical Pharmacology, vol. 72, no. 2, pp. 176-183, 2006.
[168] N. Ouslimani, J. Peynet, D. Bonnefont-Rousselot, P. Thérond, A. Legrand, and J. L. Beaudeux, "Metformin decreases intracellular production of reactive oxygen species in aortic endothelial cells," Metabolism, vol. 54, no. 6, pp. 829-834, 2005.

[169] A. J. Koupparis, J. Y. Jeremy, S. Muzaffar, R. Persad, and N. Shukla, "Sildenafil inhibits the formation of superoxide and the expression of gp47phox $\mathrm{NAD}[\mathrm{P}] \mathrm{H}$ oxidase induced by the thromboxane A2 mimetic, U46619, in corpus cavernosal smooth muscle cells," British Journal of Urology International, vol. 96, no. 3, pp. 423-427, 2005.

[170] M. Guazzi and M. Samaja, "The role of PDE5-inhibitors in cardiopulmonary disorders: from basic evidence to clinical development," Current Medicinal Chemistry, vol. 14, no. 20, pp. 2181-2192, 2007.

[171] S. Muzaffar, N. Shukla, A. Srivastava, G. D. Angelini, and J. Y. Jeremy, "Sildenafil citrate and sildenafil nitrate (NCX 911) are potent inhibitors of superoxide formation and gp91phox expression in porcine pulmonary artery endothelial cells," British Journal of Pharmacology, vol. 146, no. 1, pp. 109-117, 2005.

[172] N. Shukla, R. Jones, R. Persad, G. D. Angelini, and J. Y. Jeremy, "Effect of sildenafil citrate and a nitric oxide donating sildenafil derivative, NCX 911, on cavernosal relaxation and superoxide formation in hypercholesterolaemic rabbits," European Journal of Pharmacology, vol. 517, no. 3, pp. 224-231, 2005.

[173] J. Y. Kwak, K. Takeshige, B. S. Cheung, and S. Minakami, "Bilirubin inhibits the activation of superoxide-producing NADPH oxidase in a neutrophil cell-free system," Biochimica et Biophysica Acta, vol. 1076, no. 3, pp. 369-373, 1991.

[174] S. Lanone, S. Bloc, R. Foresti et al., "Bilirubin decreases nos2 expression via inhibition of $\mathrm{NAD}(\mathrm{P}) \mathrm{H}$ oxidase: implications for protection against endotoxic shock in rats," FASEB Journal, vol. 19, no. 13, pp. 1890-1892, 2005.

[175] A. Pflueger, A. J. Croatt, T. E. Peterson et al., "The hyperbilirubinemic Gunn rat is resistant to the pressor effects of angiotensin II," American Journal of Physiology, vol. 288, no. 3, pp. F552-F558, 2005.

[176] K. N. Agwuh and A. MacGowan, "Pharmacokinetics and pharmacodynamics of the tetracyclines including glycylcyclines," Journal of Antimicrobial Chemotherapy, vol. 58, no. 2, pp. 256265, 2006.

[177] S. H. Choi, D. Y. Lee, E. S. Chung, Y. B. Hong, S. U. Kim, and B. K. Jin, "Inhibition of thrombin-induced microglial activation and NADPH oxidase by minocycline protects dopaminergic neurons in the substantia nigra in vivo," Journal of Neurochemistry, vol. 95, no. 6, pp. 1755-1765, 2005.

[178] H. Ashrafian, J. D. Horowitz, and M. P. Frenneaux, "Perhexiline," Cardiovascular Drug Reviews, vol. 25, no. 1, pp. 76-97, 2007.

[179] J. A. Kennedy, K. Beck-Oldach, K. McFadden-Lewis et al., "Effect of the anti-anginal agent, perhexiline, on neutrophil, valvular and vascular superoxide formation," European Journal of Pharmacology, vol. 531, no. 1-3, pp. 13-19, 2006.

[180] H. Abdelghaffar, C. Babin-Chevaye, and M. T. Labro, "The macrolide roxithromycin impairs NADPH oxidase activation and alters translocation of its cytosolic components to the neutrophil membrane in vitro," Antimicrobial Agents and Chemotherapy, vol. 49, no. 7, pp. 2986-2989, 2005.

[181] R. Anderson, "Erythromycin and roxithromycin potentiate human neutrophil locomotion in vitro by inhibition of leukoattractant-activated superoxide generation and autooxidation," Journal of Infectious Diseases, vol. 159, no. 5, pp. 966973, 1989. 
[182] D. K. Perry, W. L. Hand, D. E. Edmondson, and J. D. Lambeth, "Role of phospholipase D-derived diradylglycerol in the activation of the human neutrophil respiratory burst oxidase: inhibition by phosphatidic acid phosphohydrolase inhibitors," Journal of Immunology, vol. 149, no. 8, pp. 2749-2758, 1992.

[183] M. Barua, Y. Liu, and M. R. Quinn, "Taurine chloramine inhibits inducible nitric oxide synthase and TNF- $\alpha$ gene expression in activated alveolar macrophages: decreased NF- $\kappa \mathrm{B}$ activation and I $\kappa$ B kinase activity," Journal of Immunology, vol. 167, no. 4, pp. 2275-2281, 2001.

[184] C. Kim, E. Park, M. R. Quinn, and G. Schuller-Levis, "The production of superoxide anion and nitric oxide by cultured murine leukocytes and the accumulation of TNF- $\alpha$ in the conditioned media is inhibited by taurine chloramine," Immunopharmacology, vol. 34, no. 2-3, pp. 89-95, 1996.

[185] G. Deby-Dupont, A. Mouithys-Mickalad, D. Serteyn, M. Lamy, and C. Deby, "Resveratrol and curcumin reduce the respiratory burst of Chlamydia-primed THP-1 cells," Biochemical and Biophysical Research Communications, vol. 333, no. 1, pp. 21-27, 2005.

[186] J. Leiro, E. Álvarez, J. A. Arranz, R. Laguna, E. Uriarte, and F. Orallo, "Effects of cis-resveratrol on inflammatory murine macrophages: antioxidant activity and down-regulation of inflammatory genes," Journal of Leukocyte Biology, vol. 75, no. 6, pp. 1156-1165, 2004

[187] T. M. Poolman, L. L. Ng, P. B. Farmer, and M. M. Manson, "Inhibition of the respiratory burst by resveratrol in human monocytes: correlation with inhibition of PI3K signaling," Free Radical Biology and Medicine, vol. 39, no. 1, pp. 118-132, 2005.

[188] J. Fang, J. Lu, and A. Holmgren, "Thioredoxin reductase is irreversibly modified by curcumin: a novel molecular mechanism for its anticancer activity," The Journal of Biological Chemistry, vol. 280, no. 26, pp. 25284-25290, 2005.

[189] B. Coles, A. Bloodsworth, S. R. Clark et al., "Nitrolinoleate inhibits superoxide generation, degranulation, and integrin expression by human neutrophils: novel antiinflammatory properties of nitric oxide-derived reactive species in vascular cells," Circulation Research, vol. 91, no. 5, pp. 375-381, 2002

[190] E. S. Lima, M. G. Bonini, O. Augusto, H. V. Barbeiro, H. P. Souza, and D. S. P. Abdalla, "Nitrated lipids decompose to nitric oxide and lipid radicals and cause vasorelaxation," Free Radical Biology and Medicine, vol. 39, no. 4, pp. 532-539, 2005.

[191] A. C. Allison and E. M. Eugui, "Mycophenolate mofetil and its mechanisms of action," Immunopharmacology, vol. 47, no. 2-3, pp. $85-118,2000$.

[192] F. Krötz, M. Keller, S. Derflinger et al., "Mycophenolate acid inhibits endothelial NAD(P)H oxidase activity and superoxide formation by a Racl-dependent mechanism," Hypertension, vol. 49, no. 1, pp. 201-208, 2007.

[193] B. Laleu, F. Gaggini, M. Orchard et al., "First in class, potent, and orally bioavailable NADPH oxidase isoform 4 (Nox4) inhibitors for the treatment of idiopathic pulmonary fibrosis," Journal of Medicinal Chemistry, vol. 53, no. 21, pp. 7715-7730, 2010.

[194] M. Sedeek, G. Callera, A. Montezano et al., "Critical role of Nox4-based NADPH oxidase in glucose-induced oxidative stress in the kidney: implications in type 2 diabetic nephropathy," American Journal of Physiology, vol. 299, no. 6, pp. F1348F1358, 2010.

[195] D. Gianni, N. Taulet, H. Zhang et al., "A novel and specific NADPH oxidase-1 (Noxl) small-molecule inhibitor blocks the formation of functional invadopodia in human colon cancer cells," ACS Chemical Biology, vol. 5, no. 10, pp. 981-993, 2010.
[196] S. Jones and J. Howl, "Biological applications of the receptor mimetic peptide mastoparan," Current Protein and Peptide Science, vol. 7, no. 6, pp. 501-508, 2006.

[197] D. Tisch, Y. Sharoni, M. Danilenko, and I. Aviram, "The assembly of neutrophil NADPH oxidase: effects of mastoparan and its synthetic analogues," Biochemical Journal, vol. 310, no. 2, pp. 715-719, 1995.

[198] D. Tisch-Idelson, M. Fridkin, F. Wientjes, and I. Aviram, "Structure-function relationship in the interaction of mastoparan analogs with neutrophil NADPH oxidase," Biochemical Pharmacology, vol. 61, no. 9, pp. 1063-1071, 2001.

[199] G. Yibin, Z. Jiang, Z. Hong et al., "A synthesized cationic tetradecapeptide from hornet venom kills bacteria and neutralizes lipopolysaccharide in vivo and in vitro," Biochemical Pharmacology, vol. 70, no. 2, pp. 209-219, 2005.

[200] A. Kawczynska-Drozdz, R. Olszanecki, J. Jawien et al., "Ghrelin inhibits vascular superoxide production in spontaneously hypertensive rats," American Journal of Hypertension, vol. 19, no. 7, pp. 764-767, 2006.

[201] M. L. Schubert, “Gastric secretion," Current Opinion in Gastroenterology, vol. 23, no. 6, pp. 595-601, 2007.

[202] Y. Sun, M. Asnicar, and R. G. Smith, "Central and peripheral roles of ghrelin on glucose homeostasis," Neuroendocrinology, vol. 86, no. 3, pp. 215-228, 2007.

[203] O. Cachia, J. El Benna, E. Pedruzzi, B. Descomps, M. A. Gougerot-Pocidalo, and C. L. Leger, " $\alpha$-Tocopherol inhibits the respiratory burst in human monocytes: attenuation of p47(phox) membrane translocation and phosphorylation," The Journal of Biological Chemistry, vol. 273, no. 49, pp. 3280132805, 1998.

[204] T. Egger, A. Hammer, A. Wintersperger, D. Goti, E. Malle, and W. Sattler, "Modulation of microglial superoxide production by $\alpha$-tocopherol in vitro: attenuation of p67phox translocation by a protein phosphatase-dependent pathway," Journal of Neurochemistry, vol. 79, no. 6, pp. 1169-1182, 2001.

[205] T. Kanno, T. Utsumi, Y. Takehara et al., "Inhibition of neutrophil-superoxide generation by $\alpha$-tocopherol and coenzyme Q," Free Radical Research, vol. 24, no. 4, pp. 281-289, 1996.

[206] S. K. Venugopal, S. Devaraj, T. Yang, and I. Jialal, "Alphatocopherol decreases superoxide anion release in human monocytes under hyperglycemic conditions via inhibition of protein kinase C- $\alpha$," Diabetes, vol. 51, no. 10, pp. 3049-3054, 2002.

[207] K. Ippoushi, H. Itou, K. Azuma, and H. Higashio, "Effect of naturally occurring organosulfur compounds on nitric oxide production in lipopolysaccharide-activated macrophages," Life Sciences, vol. 71, no. 4, pp. 411-419, 2002.

[208] N. Miyoshi, S. Takabayashi, T. Osawa, and Y. Nakamura, "Benzyl isothiocyanate inhibits excessive superoxide generation in inflammatory leukocytes: implication for prevention against inflammation-related carcinogenesis," Carcinogenesis, vol. 25, no. 4, pp. 567-575, 2004.

[209] D. Xiao, V. Vogel, and S. V. Singh, "Benzyl isothiocyanateinduced apoptosis in human breast cancer cells is initiated by reactive oxygen species and regulated by Bax and Bak," Molecular Cancer Therapeutics, vol. 5, no. 11, pp. 2931-2945, 2006.

[210] N. Inoue, Y. Ohara, T. Fukai, D. G. Harrison, and K. Nishida, "Probucol improves endothelial-dependent relaxation and decreases vascular superoxide production in cholesterolfed rabbits," American Journal of the Medical Sciences, vol. 315, no. 4, pp. 242-247, 1998. 
[211] H. Itoh, K. Komori, J. Okazaki et al., "The effect of probucol on intimal thickening of autologous vein grafts in hyperlipidemic rabbit," Cardiovascular Surgery, vol. 5, no. 5, pp. 497-503, 1997.

[212] S. Itoh, S. Umemoto, M. Hiromoto et al., "Importance of $\mathrm{NAD}(\mathrm{P}) \mathrm{H}$ oxidase-mediated oxidative stress and contractile type smooth muscle myosin heavy chain SM2 at the early stage of atherosclerosis," Circulation, vol. 105, no. 19, pp. 2288-2295, 2002.

[213] J. F. Keaney Jr., A. Xu, D. Cunningham, T. Jackson, B. Frei, and J. A. Vita, "Dietary probucol preserves endothelial function in cholesterol-fed rabbits by limiting vascular oxidative stress and superoxide generation," The Journal of Clinical Investigation, vol. 95, no. 6, pp. 2520-2529, 1995.

[214] F. R. DeLeo, W. M. Nauseef, A. J. Jesaitis, J. B. Burritt, R. A. Clark, and M. T. Quinn, "A domain of p47(phox) that interacts with human neutrophil flavocytochrome b558," The Journal of Biological Chemistry, vol. 270, no. 44, pp. 26246-26251, 1995.

[215] S. Wind, K. Beuerlein, T. Eucker et al., "Comparative pharmacology of chemically distinct NADPH oxidase inhibitors," British Journal of Pharmacology, vol. 161, no. 4, pp. 885-898, 2010.

[216] G. R. Drummond, S. Selemidis, K. K. Griendling, and C. G. Sobey, "Combating oxidative stress in vascular disease: NADPH oxidases as therapeutic targets," Nature Reviews Drug Discovery, vol. 10, no. 6, pp. 453-471, 2011. 


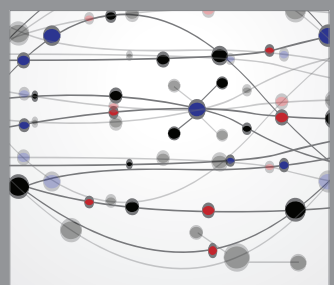

The Scientific World Journal
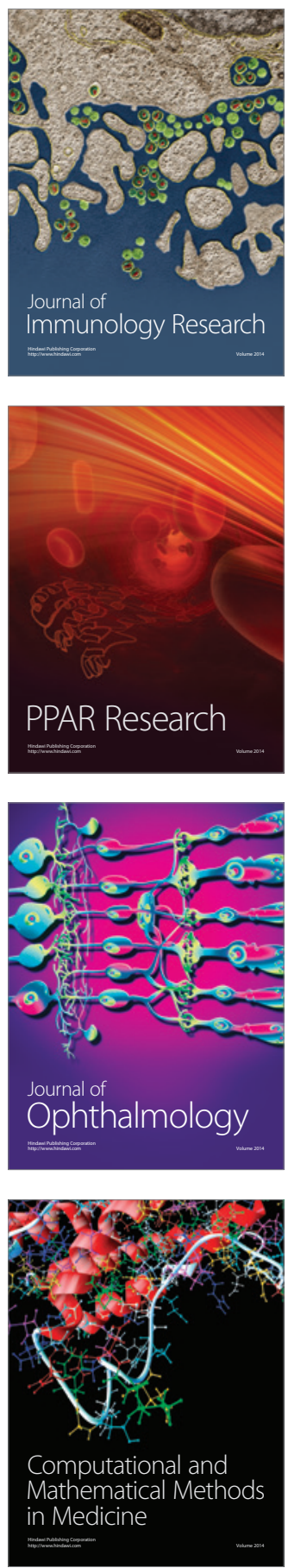

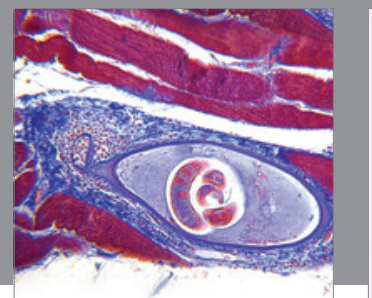

Gastroenterology

Research and Practice
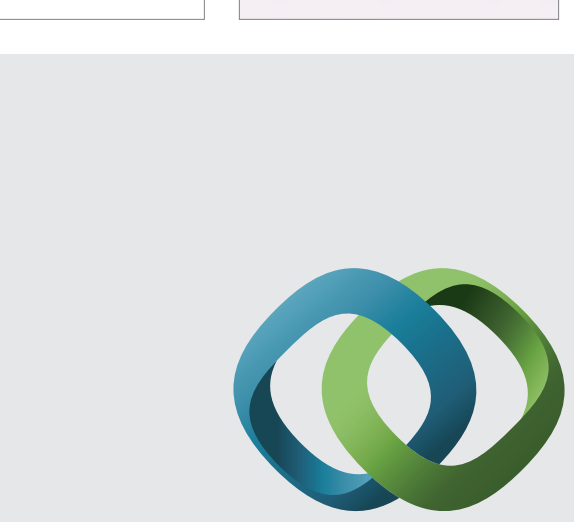

\section{Hindawi}

Submit your manuscripts at

http://www.hindawi.com
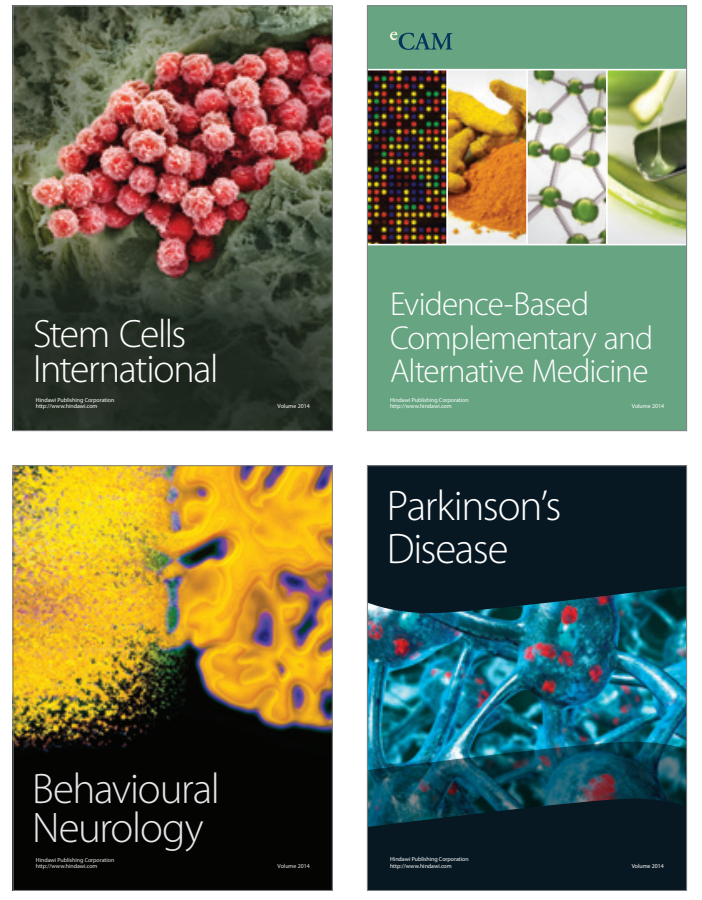
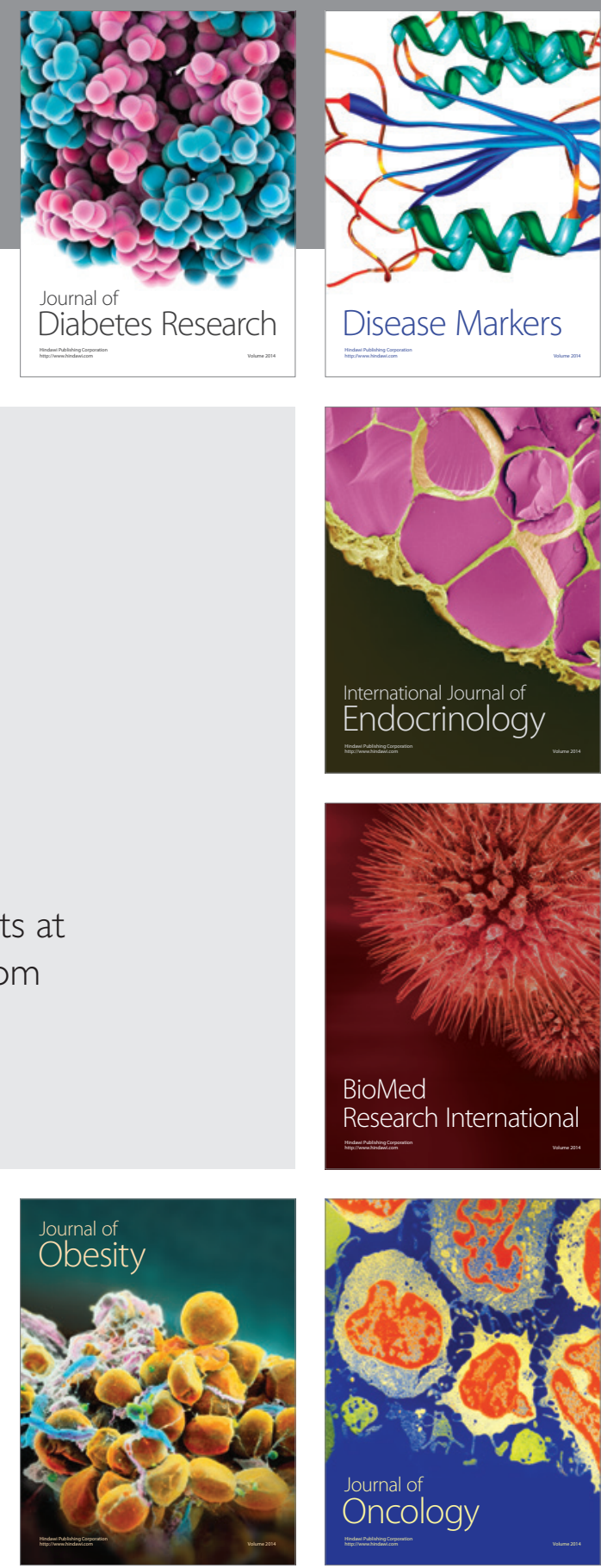

Disease Markers
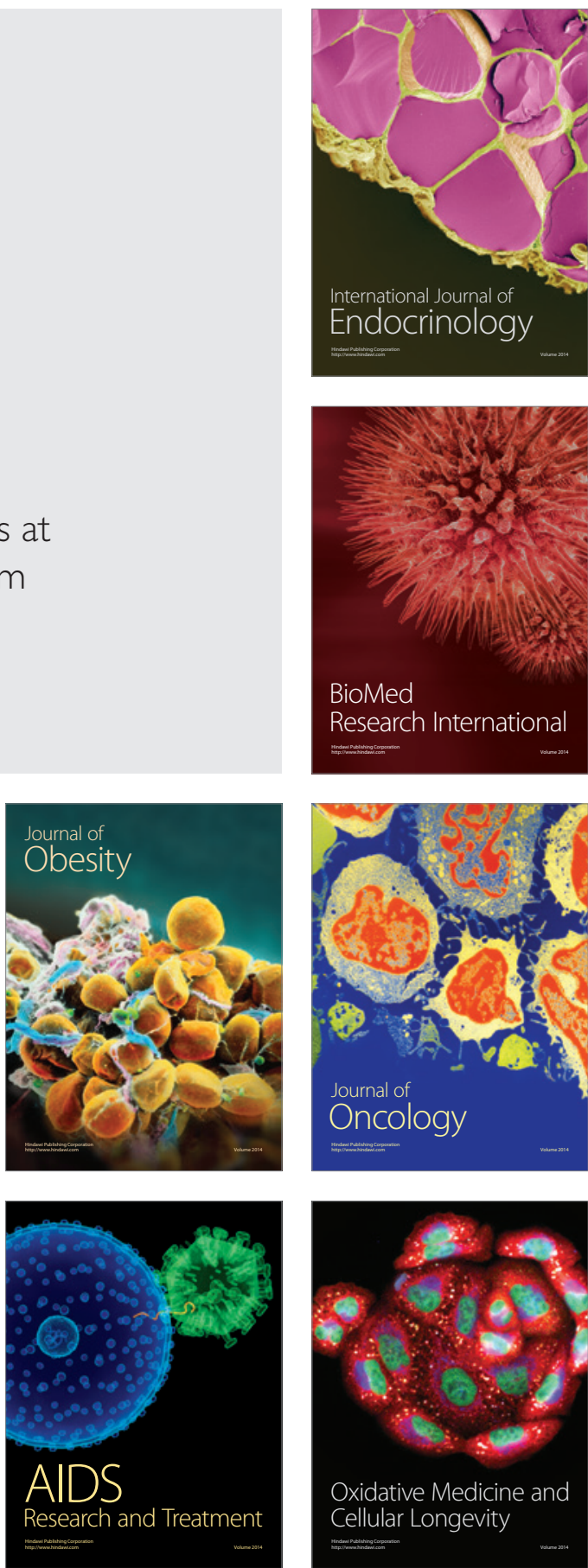